\title{
Early Cretaceous gabbroic complex from Yinan, Shandong Province: petrogenesis and mantle domains beneath the North China Craton
}

Received: 29 December 2003/ Accepted: 28 June 2004 / Published online: 28 September 2004

(C) Springer-Verlag 2004

\begin{abstract}
Sensitive high resolution ion microprobe (SHRIMP) zircon U-Pb ages, geochemical and Sr-Nd$\mathrm{Pb}$ isotopic data are reported for the gabbroic complex from Yinan (Shandong Province) with the aims of characterizing the nature of the Mesozoic mantle beneath the North China Craton. The Yinan gabbros contain alkali feldspar and biotite, and are characterized by moderate $\mathrm{Mg} \#$, high $\mathrm{SiO}_{2}$, low $\mathrm{FeO}$ and $\mathrm{TiO}_{2}$ contents and a strong enrichment of light rare earth elements $\left[(\mathrm{La} / \mathrm{Yb})_{n}=11-50\right]$, but no Eu anomaly. They have low $\mathrm{Nb} / \mathrm{La}(0.07-0.29)$, radiogenic ${ }^{87} \mathrm{Sr} /{ }^{86} \mathrm{Sr}(0.710)$ and unradiogenic $\epsilon_{\mathrm{Nd}}(t)(-15$ to -13$)$. These "crustal fingerprints" cannot be attributed to crustal contamination, given the lack of correlation between isotopic ratios and differentiation indices and the unreasonably high proportion of crustal contaminant $(>20 \%)$ required in modeling. Instead, compositional similarities to contemporaneous basalts from nearby regions imply that the Yinan gabbros were not significantly affected by crystal cumulation. Isotopic data available for the Mesozoic mafic magmas reveal two distinct mantle domains beneath Shandong. While the EM1-like domain (with low ${ }^{87} \mathrm{Sr} /{ }^{86} \mathrm{Sr}$ ) is confined to western Shandong, the mantle beneath eastern Shandong is dominated by EM2-type (with high ${ }^{87} \mathrm{Sr} /{ }^{86} \mathrm{Sr}$ ) affinities. This aerial
\end{abstract}

Y.-G. Xu (ه) J.-L. Ma · X.-L. Huang · X.-Y. Wu

Guangzhou Institute of Geochemistry,

Chinese Academy of Sciences, 510640 Wushan Guangzhou,

People's Republic of China

E-mail: yigangxu@gig.ac.cn

Tel.: + 86-20-85290109

Fax: + 86-20-85290130

Y. Iizuka

Institute of Earth sciences, Academia Sinica,

Taipei, Taiwan

S.-L. Chung

Department of Geosciences,

National Taiwan University, Taipei, Taiwan

Y.-B. Wang

Institute of Geology, Chinese Academy of Geological Sciences, 100037 Beijing, P.R. China distinction suggests that the EM2-like signature of the Yinan gabbros may have been inherited from westerlysubducted Yangtze crust during the Triassic North China-South China collision. Emplacement of the Yinan gabbros $(127 \mathrm{Ma})$ is likely affiliated with the widespread and protracted extension during the late Mesozoic in this region.

Keywords Geochemistry - Zircon U-Pb age · Gabbros $\cdot$ Mantle $\cdot$ North China Craton

\section{Introduction}

The geology of the North China Craton (NCC) has received much attention not only because it is one of the oldest continental nuclei in the world (up to $3.8 \mathrm{Ga}$; Jahn et al. 1987; Liu et al. 1992), but also owing to the presence of a variety of mafic magmas of different ages. Geochemical characterization of these mantle-derived magmas, particularly the Paleozoic diamondiferous kimberlites and Cenozoic basalts and their entrained xenoliths, has been used to investigate mantle evolution in this region (e.g., Fan and Menzies 1992; Menzies et al. 1993; Griffin et al. 1998; Menzies and Xu 1998; Fan et al. 2000; Xu 2001; Zhang et al. 2002). The general scenario that has emerged from these studies is that the thick, old, cold and refractory lithospheric keel (preserved at least until the Palaeozoic) has been replaced by a thin, young, hot and fertile mantle. Better understanding of this process is of great importance, not only for deep dynamics and regional geology investigations (Menzies and $\mathrm{Xu}$ 1998), but also for exploration of mineral resources (e.g., Yang et al. 2003). It has been proposed that the lithospheric destruction must have taken place during the late Mesozoic, probably owing to the loss of physical integrity of the craton as a result of the Triassic collision between the North China and Yangtze blocks (Xu 2001; Gao et al. 2002; Zhang et al. 2002). Nevertheless, the timing and nature of this event still remain 
poorly explained, largely owing to the lack of knowledge about the Mesozoic lithosphere that links the Palaeozoic and Cenozoic lithospheres.

Mesozoic plutonism is widely distributed in the NCC. Plutonic rocks are generally fresher than the volcanic phases, and range from gabbro diorite to granodiorite. These intrusions have been targeted for chronological, geochemical and isotopic analyses. In this paper, we present sensitive high resolution ion microprobe (SHRIMP) zircon $\mathrm{U}-\mathrm{Pb}$ ages, petrology, major, trace element and $\mathrm{Sr}-\mathrm{Nd}-\mathrm{Pb}$ isotopic data on a suite of gabbroic samples from Yinan, Shandong Province. We are particularly concerned with the petrogenesis of this intrusion and the nature of the mantle members involved in magma generation. The mantle signature in these Mesozoic rocks, together with those available in the literature will be used to define the spatial distribution of mantle domains beneath the NCC.

\section{Geological background}

As the core of the NCC, Shandong Province has been targeted for extensive studies on mantle evolution in the past decade. In particular, the juxtaposition of xenolithbearing Ordovician diamondiferous kimberlites and Cenozoic alkali basalts in this province (Fig. 1a) provides key information concerning the temporal change of the lithosphere. It is based on the comparison of Paleozoic and Cenozoic lithospheric mantles that the contention of destruction of the lithospheric keel has been reached among the scientific community (Menzies et al. 1993; Griffin et al. 1998; Xu 2001). In addition to the Paleozoic kimberlites and Cenozoic basalts, Mesozoic plutonism and mafic volcanism are also present in this region. Geochemical characterization of these rocks should shed light on the nature of the Mesozoic mantle that is pivotal to the understanding of mantle evolution beneath the NCC (Zhang et al. 2002).

A prominent geologic feature in the NCC is the NEEtrending Tan-Lu fault zone (TLFZ) which runs over $4,000 \mathrm{~km}$ from the southern margin of the NCC to the Russian Far East (Fig. 1a). It has been interpreted as a major transcurrent intracontinental fault zone of over $700 \mathrm{~km}$ sinistral displacement, with most of the offset thought to have taken place in the Cretaceous $(\mathrm{Xu}$ 1993). This sinistral movement probably displaced the east part of the Qinling-Dabie ultra-high-pressure
Fig. 1 a Simplified geological map of eastern China (modified after $\mathrm{Xu}, 2002)$. b Distribution of Mesozoic intrusive and eruptive rocks in Shandong Province and the location of the Yinan gabbroic complex
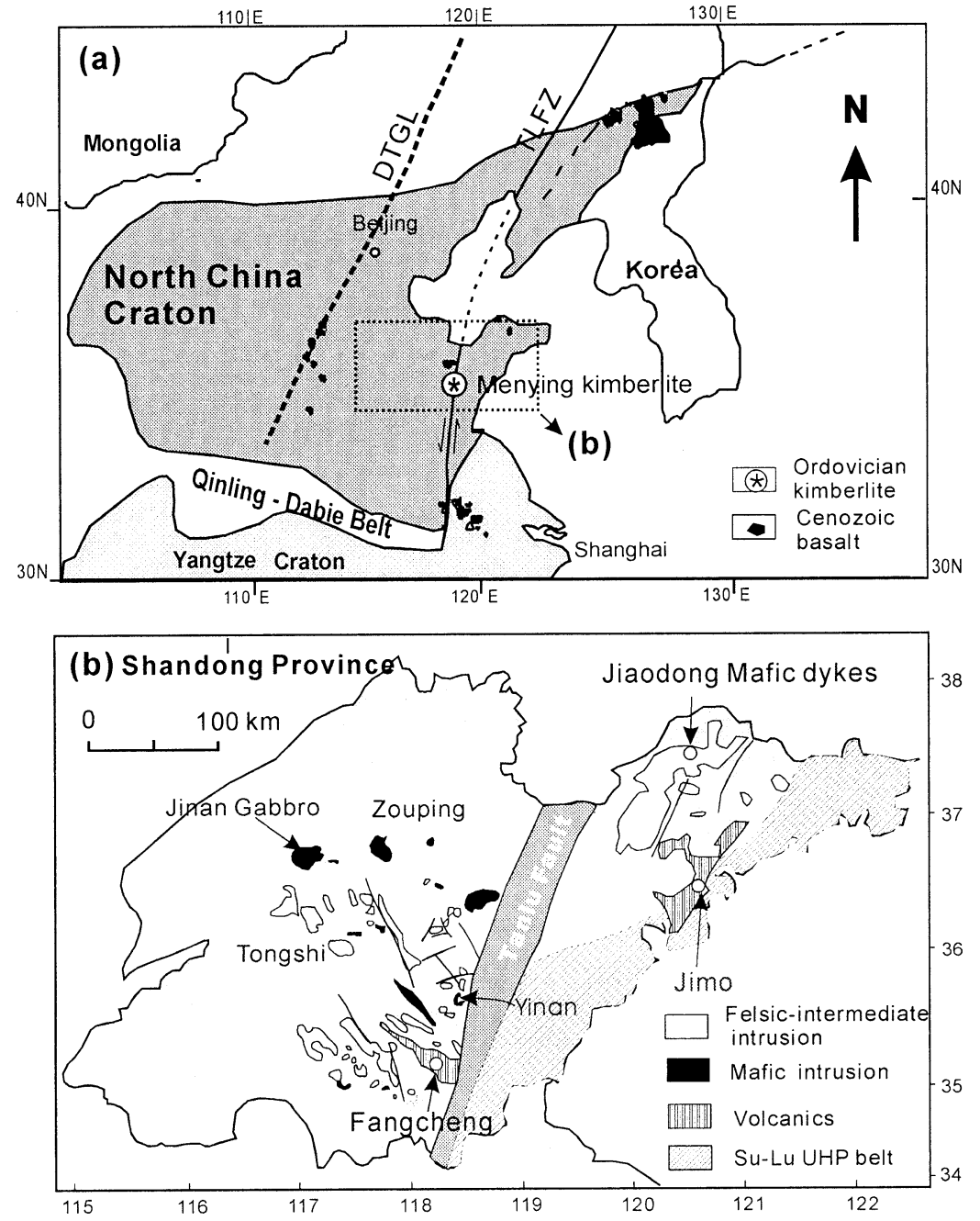
(UHP) metamorphic belt to the present position (i.e., the Su-Lu UHP metamorphic belt) (Li 1994). The TLFZ separates Shandong Province into two geologically different parts (Fig. 1b). The western part is called Luxi, and the eastern Jiaodong. Mesozoic igneous rocks in this province consist of dominant plutons and subordinate volcanic rocks. The petrology of the intrusive rocks in the Luxi area has been studied by Xu et al. (1993) and Tan and Lin (1994). Field relationships (Tan and Lin, 1994) and available $\mathrm{K}-\mathrm{Ar}$ radiometric data (Xu et al. 1993) suggest that magmas were emplaced during the late Mesozoic (100-140 Ma). Contrasting isotopic compositions have been noted for Mesozoic mafic rocks from the two regions separated by the Tanlu fault. The lavas from Jiaodong show an EM2-like isotopic signature (Fan et al. 2001; Yang et al. 2004), whereas the EM1-like signature is essentially associated with those from Luxi (Guo et al. 2001; 2003). However, the Fangcheng basalts (Zhang et al. 2002), located west of the TLFZ, are also characterized by an EM-2 type signature. This suggests that the TLFZ may not correspond to a lithospheric boundary.

Mesozoic intrusions in the Yinan region are located west of and proximal to the TLFZ (Fig. 1b). They consist of a number of small intrusive rocks, with a total outcrop surface of $\sim 30 \mathrm{~km}^{2}$. The Yinan intrusive complexes were emplaced into Cambrian-Ordovician strata, but the overlying sediments suggest a Cretaceous emplacement age. The rocks range widely in composition, and include gabbros, diorites, granodiorites and granites. Rocks of mafic composition are the focus of this study.

\section{Petrography}

The gabbroic samples were collected from a quarry near the Shangyu village, Yinan County $\left(35^{\circ} 26^{\prime} 46^{\prime \prime} \mathrm{N}\right.$; $\left.118^{\circ} 19^{\prime} 18^{\prime \prime} \mathrm{E}\right)$. They are generally fresh without visible alteration and are medium- to coarse-grained rocks, composed mainly of plagioclase, alkali feldspar, clinopyroxene $(\mathrm{Cpx})$, olivine $(\mathrm{Ol})$ and biotite with minor orthopyroxene $(\mathrm{Opx})$. Accessory phases include $\mathrm{Fe}-\mathrm{Ti}$ oxides, apatite, zircon and sphene. Plagioclase and Cpx appear to have co-precipitated and the latter contains plagioclase inclusions (Fig. 2a). Unlike typical cumulate gabbros, the Yinan gabbros contain up to $18 \%$ alkali feldspar. Cpx is the most abundant mafic mineral, making up to $40 \%$ of the whole rock. It commonly shows simple normal zoning, but some large grains show complex zoning patterns (Fig. 2b). Ol occurs subordinately within the interstitial alkali feldspars or as inclusions in Cpx. Opx forms discontinuous rims around these Ols (Fig. 2c). In some instances, Opx and magnetite formed as symplectite in the periphery of Ol.

Hornblende, which is common in gabbroic complexes, is not observed in the Yinan case. Instead, large flakes of foxy-red biotite are present and make up 4$26 \%$ by volume of the Yinan gabbros. In most cases, biotite occurs interstitially to other mafic crystals (Fig. 2d). Sometimes biotite occurs as inclusions in Cpx.

\section{Materials and methods}

Analytical techniques Analyses of mineral phases were carried out at the Institute of Earth Sciences, Academia Sinica (Taiwan) with a JEOL Superprobe. The operating conditions were as follows: $15 \mathrm{kV}$ accelerating voltage, $10 \mathrm{nA}$ beam current and $1 \mu \mathrm{m}$ beam diameter. A program based on the ZAF correction procedure was used for data reduction. Bulk abundances of major elements were determined using inductively coupled plasmaatomic emission spectrometry (ICP-AES) at the Guangzhou Institute of Geochemistry, Chinese Academy of Sciences (GIGCAS). Analytical uncertainties for the majority of major elements were estimated to be $<1 \%$. Bulk-rock trace element data [rare earth elements (REE), Sr, Y, Ba, U, Rb, Th, Pb, Zr, Hf, Nb, Ta] were obtained by inductively coupled plasma-mass spectrometry (ICP-MS) at GIGCAS. Analytical procedures and precision have been described elsewhere (Xu, 2002).

For $\mathrm{Sr}-\mathrm{Nd}$ isotopic analyses, sample powders $\left(\sim 100 \mathrm{mg}\right.$ ) were dissolved in distilled $\mathrm{HF}-\mathrm{HNO}_{3}$ in Savillex screwtop Teflon beakers at $150{ }^{\circ} \mathrm{C}$ overnight. $\mathrm{Sr}$ and REE were separated on columns made of $\mathrm{Sr}$ and REE resins of the Eichrom Company using $0.1 \% \mathrm{HNO}_{3}$ as elutant. Separation of Nd from the REE fractions was carried out on HDEHP columns with a $0.18 \mathrm{~N} \mathrm{HCl}$ elutant. The isotopic analyses were performed using a Micromass Isoprobe multi-collector-ICP-MS (MC-ICPMS) at GIGCAS. Measured $\mathrm{Sr}$ and $\mathrm{Nd}$ isotopic ratios were normalized using a ${ }^{86} \mathrm{Sr}{ }^{88} \mathrm{Sr}$ value of 0.1194 and a ${ }^{146} \mathrm{Nd} /{ }^{144} \mathrm{Nd}$ value of 0.7219 , respectively. Analyses of standards during the period of analysis are as follows: NBS987 gave ${ }^{87} \mathrm{Sr} /{ }^{86} \mathrm{Sr}=0.710243 \pm 14(2 \sigma)$; Shin Etou gave ${ }^{143} \mathrm{Nd} /{ }^{144} \mathrm{Nd}=0.512124 \pm 11(2 \sigma)$, equivalent to a value of 0.511860 for the La Jolla international standard (Tanaka et al. 2000). For Pb isotopic analyses, $\sim 200 \mathrm{mg}$ powder was dissolved in concentrated HF for 3 days. $\mathrm{Pb}$ was separated and purified by conventional cation-exchange techniques (200-400 mesh AG1X8 resin) with diluted $\mathrm{HBr}$ as eluant. $\mathrm{Pb}$ isotopes were determined using a VG-354 mass spectrometer at the Institute of Geology, Chinese Academy of Sciences (Beijing). Analyses of standard NBS981 during the period of analysis yielded ${ }^{204} \mathrm{~Pb} /{ }^{206} \mathrm{~Pb}=0.0897 \pm 15,{ }^{207} \mathrm{~Pb} /{ }^{206} \mathrm{~Pb}=0.91445 \pm 80$, and ${ }^{208} \mathrm{~Pb} /{ }^{206} \mathrm{~Pb}=2.16170 \pm 200$.

Zircons were separated from the sample YN-31 using conventional heavy liquid and magnetic techniques and purified by handpicking under a binocular microscope. The internal structure of zircons was examined using the cathodoluminescence $(\mathrm{CL})$ image technique prior to $\mathrm{U}-\mathrm{Pb}$ isotopic analyses. The $\mathrm{U}-\mathrm{Pb}$ analyses were performed using a SHRIMP II at the Institute of Geology, Chinese Academy of Geological Sciences, Beijing. Detailed analytical procedures are similar to those 

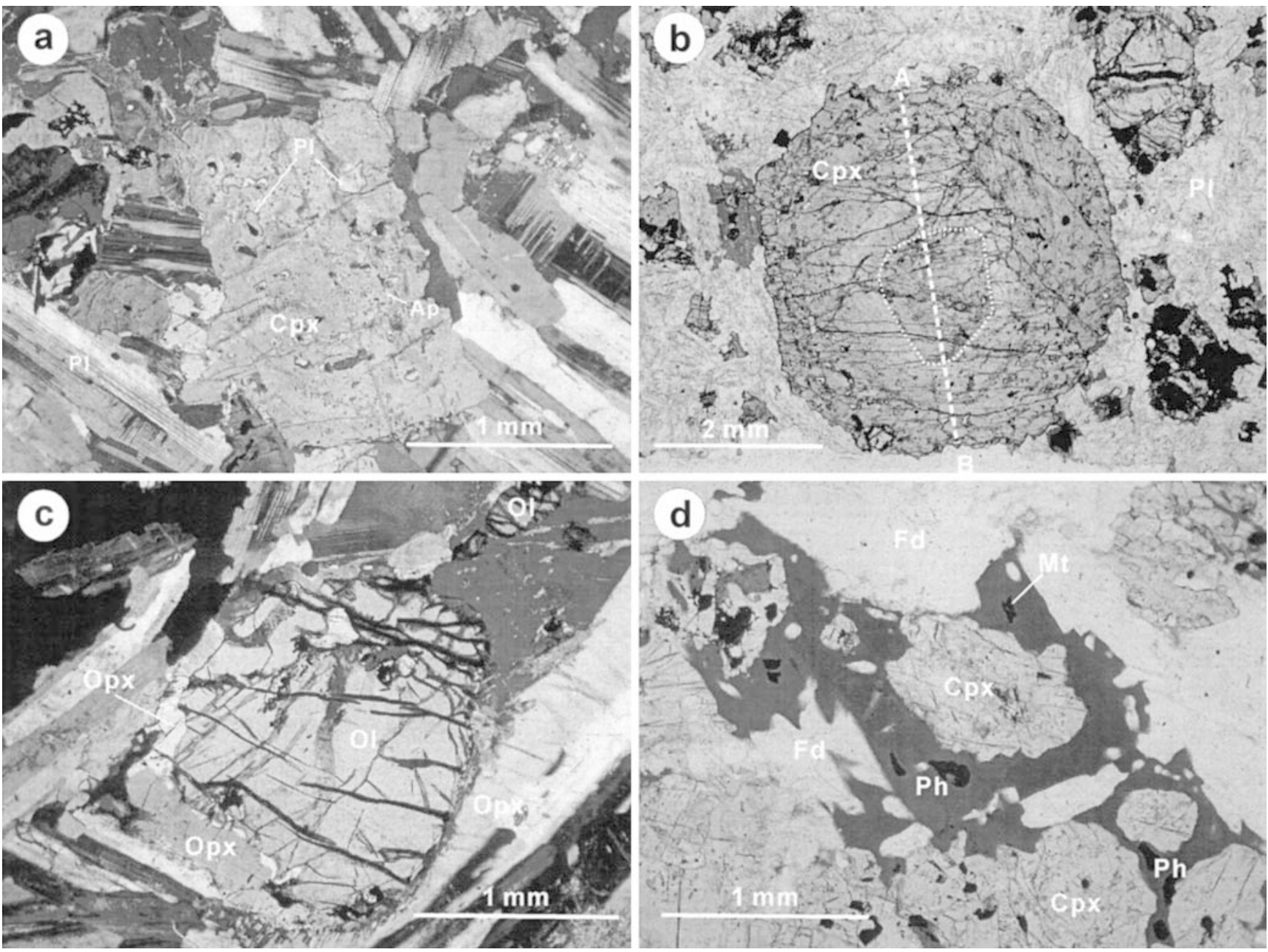

Fig. 2a-d Photomicrographs showing the petrographic features of the Yinan gabbros. a Poikilitic clinopyroxene $(C p x)$ with plagioclase $(P l)$ and apatite $(A p)$ inclusions (YN-27). b Zoned Cpx outlining the core of this zoned mineral. Dashed line $(A-B)$ marks the traverse analyses by electron microprobe. c Olivine $(O l)$ rimmed by orthopyroxene (Opx) (YN-31). d Large flakes of biotite $(P h)$ with magnetite $(M t)$ inclusions occur interstitially with alkali feldspars $(F d)$, or adjacent to the rims of mafic minerals (YN-27)

described by Williams et al. (1998). The standard TEM zircons (age $417 \mathrm{Ma}$ ) of RSES were used to determine interelement fractionation, and $\mathrm{U}, \mathrm{Th}$ and $\mathrm{Pb}$ concentrations were determined based on the standard Sri Lankan gem zircon SL13, which has a U concentration of $238 \mathrm{ppm}$ corresponding to an age of $572 \mathrm{Ma}$. Data processing was carried out using the SQUID 1.03 and

Table 1 SHRIMP zircon U-Pb dating of the sample YN-31. $f_{206}$ Percentage of non-radiogenic $\mathrm{Pb}$

\begin{tabular}{|c|c|c|c|c|c|c|c|c|c|c|}
\hline Spot & $\begin{array}{l}\mathrm{U} \\
(\mathrm{ppm})\end{array}$ & $\begin{array}{l}\text { Th } \\
\text { (ppm) }\end{array}$ & $\mathrm{Th} / \mathrm{U}$ & $\begin{array}{l}{ }^{206} \mathrm{~Pb} \\
(\mathrm{ppm})\end{array}$ & $\begin{array}{l}f_{206} \\
(\%)\end{array}$ & $\begin{array}{l}{ }^{204} \mathrm{~Pb} /{ }^{206} \mathrm{~Pb} \\
\pm 1 \sigma\end{array}$ & $\begin{array}{l}{ }^{207} \mathrm{~Pb} /{ }^{206} \mathrm{~Pb} \\
\pm 1 \sigma\end{array}$ & $\begin{array}{l}{ }^{207} \mathrm{~Pb} /{ }^{235} \mathrm{U} \\
\pm 1 \sigma\end{array}$ & $\begin{array}{l}{ }^{206} \mathrm{~Pb} /{ }^{238} \mathrm{U} \\
\pm 1 \sigma\end{array}$ & $\begin{array}{l}{ }^{206} \mathrm{~Pb} /{ }^{238} \mathrm{U} \\
\text { Age }(\mathrm{Ma}) \pm 1 \sigma\end{array}$ \\
\hline 1 & 155 & 187 & 1.25 & 2.70 & 3.58 & $0.0019 \pm 8$ & $0.0330 \pm 135$ & $0.0890 \pm 365$ & $0.0195 \pm 7$ & $125 \pm 4$ \\
\hline 3 & 442 & 799 & 1.87 & 7.72 & 0.40 & $0.0002 \pm 1$ & $0.0496 \pm 21$ & $0.1386 \pm 72$ & $0.0203 \pm 6$ & $129 \pm 4$ \\
\hline 4 & 183 & 273 & 1.55 & 3.13 & 1.23 & $0.0007 \pm 4$ & $0.0463 \pm 56$ & $0.1260 \pm 164$ & $0.0197 \pm 6$ & $126 \pm 4$ \\
\hline 5 & 173 & 242 & 1.44 & 3.00 & 1.75 & $0.0009 \pm 2$ & $0.0417 \pm 46$ & $0.1140 \pm 125$ & $0.0198 \pm 6$ & $127 \pm 4$ \\
\hline 9 & 189 & 273 & 1.49 & 3.36 & 1.81 & $0.0010 \pm 4$ & $0.0327 \pm 62$ & $0.0920 \pm 175$ & $0.0203 \pm 6$ & $130 \pm 4$ \\
\hline 10 & 220 & 335 & 1.57 & 3.80 & 1.72 & $0.0009 \pm 2$ & $0.0394 \pm 39$ & $0.1070 \pm 107$ & $0.0198 \pm 6$ & $126 \pm 4$ \\
\hline 11 & 157 & 216 & 1.42 & 2.75 & 0.07 & $0.0000 \pm 5$ & $0.0520 \pm 73$ & $0.1460 \pm 219$ & $0.0204 \pm 7$ & $130 \pm 4$ \\
\hline 12 & 257 & 358 & 1.44 & 4.55 & 0.04 & $0.0000 \pm 1$ & $0.0495 \pm 26$ & $0.1404 \pm 86$ & $0.0206 \pm 6$ & $131 \pm 4$ \\
\hline 13 & 171 & 243 & 1.47 & 2.95 & 1.91 & $0.0010 \pm 3$ & $0.0360 \pm 54$ & $0.0980 \pm 157$ & $0.0197 \pm 6$ & $126 \pm 4$ \\
\hline 14 & 517 & 1,027 & 2.05 & 8.80 & 0.84 & $0.0005 \pm 2$ & $0.0410 \pm 27$ & $0.1111 \pm 80$ & $0.0197 \pm 6$ & $126 \pm 4$ \\
\hline
\end{tabular}


Fig. $3 \mathrm{U}-\mathrm{Pb}$ zircon concordia diagram for the gabbroic sample YN-31 from Yinan. Inset shows the cathodoluminescence image of representative zircons. Scale bar $=100 \mu \mathrm{m}$. Most of the analyses are concordant, yielding a weighted mean ${ }^{206} \mathrm{~Pb} /{ }^{238} \mathrm{U}$ age of $127 \pm 2 \mathrm{Ma}$

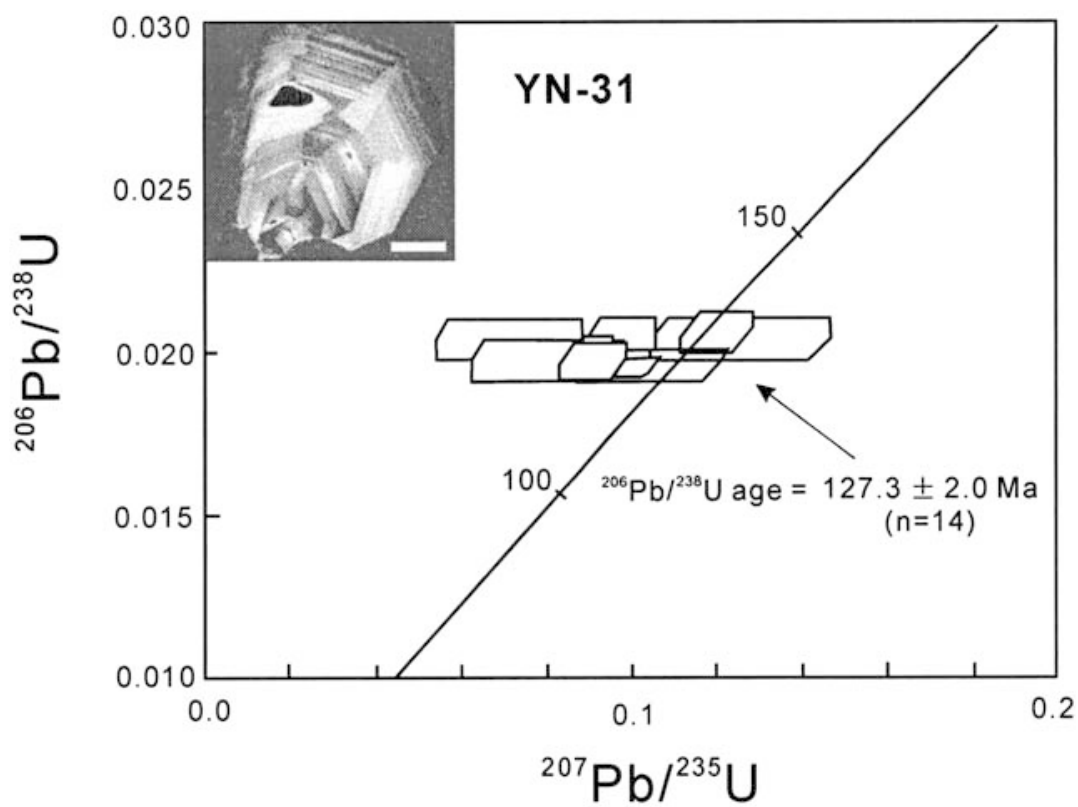

Isoplot/Ex 2.49 programs of Ludwig (2001a, 2001b), and the ${ }^{204} \mathrm{~Pb}$-based method of common $\mathrm{Pb}$ correction was applied. The ages quoted in the text are ${ }^{206} \mathrm{~Pb} /{ }^{238} \mathrm{U}$ ages, which are the weighted means at the $95 \%$ confidence level.

\section{Results}

\section{$\mathrm{U}-\mathrm{Pb}$ zircon chronology}

The results of SHRIMP U-Pb zircon analyses for the sample YN-31 are listed in Table 1 and illustrated in a concordia plot (Fig. 3). Zircons are large and commonly fragmented owing to rock crushing during zircon extraction. Nevertheless, the well-developed tetragonal dipyramids in these crystals indicate the original euhedral shape of these crystals. The oscillatory zoning (see inset of Fig. 3) further suggests an igneous origin. These zircon grains have a relatively wide range in U (132$624 \mathrm{ppm})$ and Th (178-1,528 ppm) concentrations. $\mathrm{Th} / \mathrm{U}$ ratios of these zircons are rather constant $(\sim 1.5)$ except three grains with $\mathrm{Th} / \mathrm{U}$ ratios greater than 2 . Analyses of 14 zircons (Table 1) yielded concordant or near concordant ages. A weighted mean ${ }^{206} \mathrm{~Pb} /{ }^{238} \mathrm{U}$ age of $127 \pm 2 \mathrm{Ma}$ was obtained based on all analyses (Fig. 3). This age is interpreted as the timing of emplacement of the Yinan gabbros.

\section{Mineral chemistry}

Ols are unzoned with forsterite content ranging from 57-66 mol\% (Table 2). Opxs forming discontinuous rims around $\mathrm{Ol}$ have the slightly higher $\mathrm{Mg} \#$ of $0.63-$ 0.74. Extremely low $\mathrm{Al}_{2} \mathrm{O}_{3}$ and $\mathrm{Cr}_{2} \mathrm{O}_{3}$ contents in $\mathrm{Opx}$ (Table 2) probably reflect the compositional inheritage of Ol. Cpxs are mostly augite in composition showing a normal chemical zoning with $\mathrm{Mg} \#$ varying from 0.87 in the core to 0.70 in the rim. However, some Cpx grains show complex zoning patterns (Fig. 4a), probably related to magma recharge and fractionation in the magma chamber.

Plagioclase grains are not compositionally homogeneous (Table 3). They are characterized by low anorthite content $\left(\mathrm{An}_{21-54}\right)$ compared to typical gabbros from around world. Alkali feldspars are also present with Or content up to $75 \mathrm{~mol} \%$.

Biotite is phlogopite-rich (Table 4). As noted from Fig. 4b, the decrease in $\mathrm{Mg \#}$ is accompanied by increasing $\mathrm{TiO}_{2}$. Biotites occurring as rims around $\mathrm{Opx}$ generally have higher $\mathrm{Mg} \#$ and lower $\mathrm{TiO}_{2}$ content than interstitial ones (Table 4).

\section{Major and minor elements}

Whole rock analyses are listed in Table 5 and graphically illustrated in Fig. 5 and Fig. 6. Mesozoic basalts from Fangcheng and Cenozoic basalts from Shandong Province are shown for comparison. Most of the Yinan gabbros have high alkali contents and belong to the medium-K and high-K calc-alkaline series (Fig. 5); the $\mathrm{Mg} \#$ range is $0.58-0.66$. This reflects either their moderately fractionated characters or a relatively Fe-rich source. In Fig. 6, the Yinan gabbros and the Fangcheng basalts define coherent variation trends. $\mathrm{SiO}_{2}, \mathrm{Al}_{2} \mathrm{O}_{3}$ and $\mathrm{Na}_{2} \mathrm{O}$ are negatively correlated with $\mathrm{MgO}$, whereas $\mathrm{TiO}_{2}, \mathrm{CaO}, \mathrm{FeO}, \mathrm{Cr}$ and Ni positively correlate with $\mathrm{MgO}$. Compared to the Cenozoic lavas, the Mesozoic mafic intrusions and lavas display higher $\mathrm{SiO}_{2}, \mathrm{Al}_{2} \mathrm{O}_{3}$, and lower $\mathrm{FeO}, \mathrm{TiO}_{2}$ and $\mathrm{Ni}$ contents at comparable $\mathrm{MgO}$ (Fig. 6). 


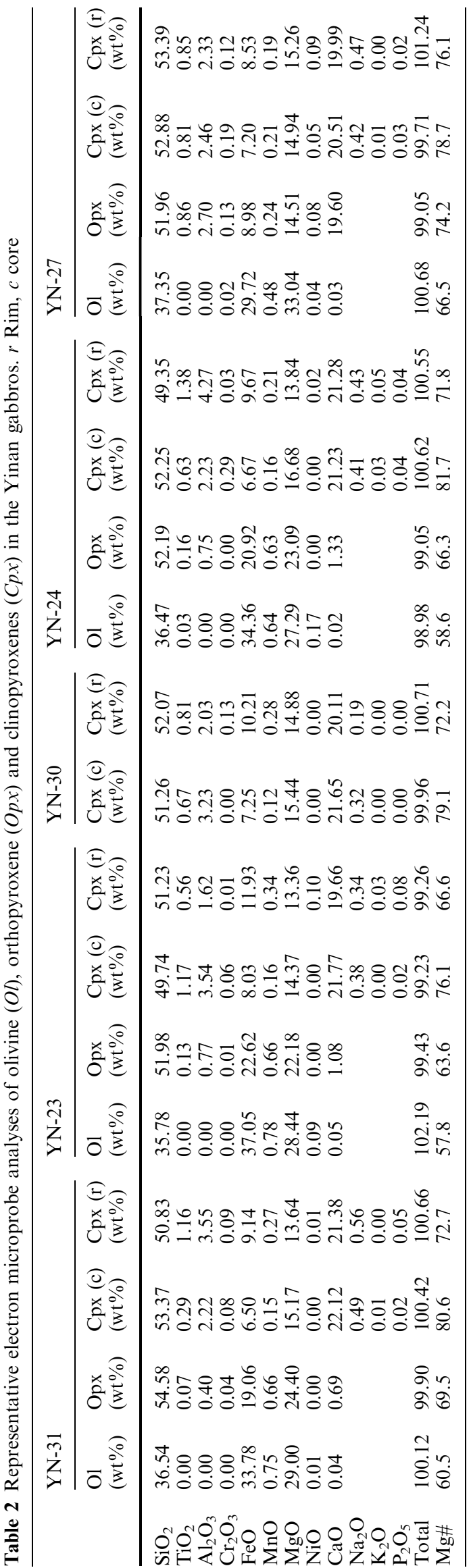

(a) Clinopyroxene
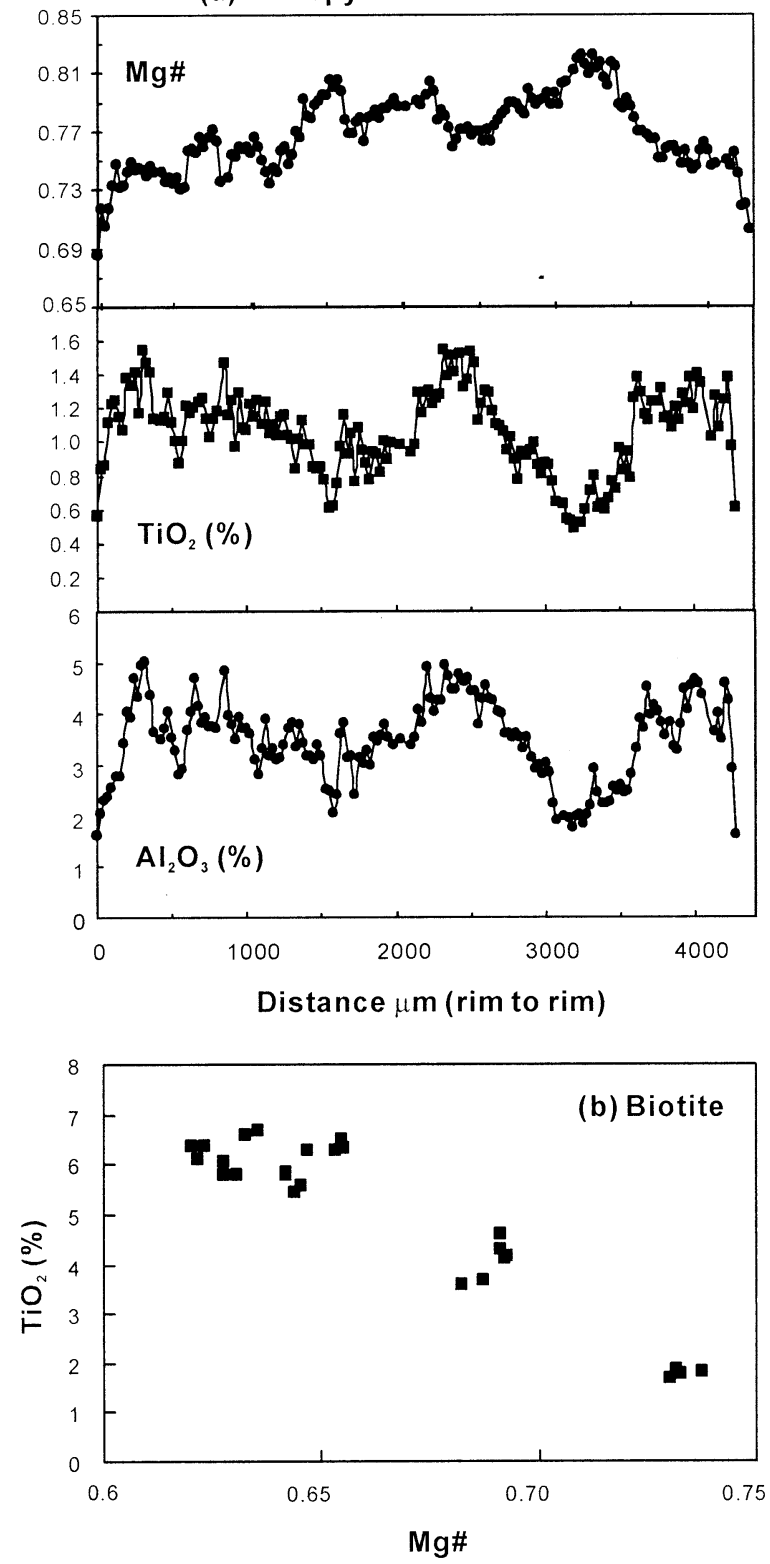

Fig. 4 a Complex zoning pattern in Cpx in the sample YN-24 (line A-B in Fig. 2b). b Negative correlation between $\mathrm{TiO}_{2}$ and $\mathrm{Mg} \#$ of biotites in the Yinan gabbros

Trace elements

The Yinan gabbros are characterized by a pronounced enrichment of LREE $\left([\mathrm{La} / \mathrm{Yb}]_{n}=11.2-54.5\right)$ and other large ion lithophile elements (LILE) such as $\mathrm{Rb}, \mathrm{Ba}$ and $\mathrm{K}$, and strong depletion in high field-strength elements (HFSE) (Fig. 7). No Eu anomaly is observed. The sample YN-23 stands out because of its low REE content. This sample also shows a positive $\mathrm{Sr}$ anomaly. Overall, the trace element compositions of the Yinan gabbros are reminiscent of those of the Fangcheng basalts (Zhang et al. 2002) and differ from those of the Cenozoic basalts, which show patterns similar to those 
Table 3 Representative electron microprobe analyses of feldspars in the Yinan gabbros. An Anorthite, $A b$ albite, $O r$ orthoclase

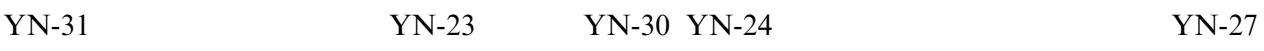

Plag Plag Plag K-feld Plag K-feld Plag Plag Plag Plag K-feld K-feld Plag Plag Plag K-feld K-feld $(w t \%)(w t \%)(w t \%)(w t \%)(w t \%)(w t \%)(w t \%) \quad(w t \%)(w t \%)(w t \%)(w t \%)(w t \%)(w t \%)(w t \%)(w t \%)(w t \%)(w t \%)$

\begin{tabular}{|c|c|c|c|c|c|c|c|c|c|c|c|c|c|c|c|c|c|}
\hline $\mathrm{SiO}_{2}$ & 4.97 & 9.29 & 63.94 & 64.53 & 61.72 & 63.85 & 61.74 & 55.27 & 57.74 & 61.06 & 64.32 & 63.77 & 56.46 & 59.84 & 61.55 & 65.01 & 65.44 \\
\hline $\mathrm{TiO}_{2}$ & 0.02 & .01 & .08 & 0.08 & 0.02 & 0.13 & 0.00 & 0.06 & 0.06 & 0.07 & & 0.12 & 0.03 & 0.07 & 0.02 & & 0.11 \\
\hline $\mathrm{Al}_{2} \mathrm{O}_{3}$ & 28.27 & 5.49 & 2.36 & 19.58 & 24.10 & 20.12 & 24.19 & 28.70 & 26.57 & 25.24 & 20.64 & 19.53 & 27.60 & 25.78 & 4.07 & 9.71 & 18.63 \\
\hline $\mathrm{Cr}_{2} \mathrm{O}_{3}$ & .00 & 0.01 & 0.02 & 0.00 & 0.00 & 0.00 & 0.04 & 0.03 & 0.00 & 0.06 & 0.04 & 0.03 & 0.01 & 0.03 & 0.00 & 0.01 & 0.00 \\
\hline $\mathrm{FeO}$ & .17 & 0.37 & 0.45 & 0.26 & 0.33 & 0.17 & 0.38 & 0.26 & 0.29 & 0.25 & 0.11 & 0.17 & 0.19 & 0.22 & 0.17 & .24 & 0.14 \\
\hline $\mathrm{MnO}$ & 0.00 & 00 & 00 & 0.00 & 0.03 & 0.05 & 0.03 & 0.01 & 0.00 & 0.01 & 0.00 & 0.05 & 0.03 & 0.00 & 0.00 & 0 & 0.01 \\
\hline $\mathrm{MgO}$ & 0.00 & c & & & 0.0 & & & & 0. & & & 0.0 & & 0.0 & 0.0 & 0 & 0.0 \\
\hline $\mathrm{NiO}$ & 0.00 & 0 & & & & & & & & & & & & & & & 0 \\
\hline $\mathrm{aO}$ & 1.66 & 7 & & 0 & 6.1 & & & 10.73 & & & & & & 8. & & & \\
\hline $\mathrm{Na}_{2} \mathrm{O}$ & 33 & & & & & & & & & & & & & & & & 2.00 \\
\hline $\mathrm{K}_{2} \mathrm{O}$ & .44 & .22 & 47 & 8.99 & 0.35 & 9.27 & 0.29 & 0.2 & & & & & & & & & 12.62 \\
\hline $\mathrm{P}_{2} \mathrm{O}_{5}$ & .06 & 0 & & 0.0 & & & & & & & & & & & & & .00 \\
\hline Total & 9.93 & & & & & & & & & & & & & & 0.05 & & 9.52 \\
\hline An & & & & & & & & & & & & & & & & & \\
\hline $\mathrm{Ab}$ & & & & & & & & & & & & & & & & & 0.19 \\
\hline Or & 0.03 & 0.01 & 0.03 & 0.56 & 0.02 & 0.64 & 0.02 & 0.02 & 0.02 & 0.02 & 0.51 & 0.76 & 0.02 & 0.03 & 0.02 & 0.63 & 0.78 \\
\hline
\end{tabular}

Table 4 Representative elctron microprobe analyses of biotites in the Yinan gabbros

\begin{tabular}{|c|c|c|c|c|c|c|c|c|c|c|c|c|}
\hline & \multicolumn{4}{|l|}{ YN-31 } & \multicolumn{2}{|l|}{ YN-23 } & \multicolumn{2}{|l|}{ YN-30 } & \multicolumn{2}{|l|}{$\mathrm{YN}-24$} & \multicolumn{2}{|l|}{ YN-27 } \\
\hline & $(w t \%)$ & $(\mathrm{wt} \%)$ & $(w t \%)$ & $(w t \%)$ & $\begin{array}{l}\text { Core } \\
\left(w t^{\circ} \%\right)\end{array}$ & $\begin{array}{l}\text { Rim } \\
(w t \%)\end{array}$ & $(\mathrm{wt} \%)$ & $(\mathrm{wt} \%)$ & $(\mathrm{wt} \%)$ & $(\mathrm{wt} \%)$ & $(w t \%)$ & $(w t \%)$ \\
\hline $\mathrm{SiO}_{2}$ & 38.81 & 38.75 & 37.60 & 38.34 & 37.02 & 36.82 & 40.16 & 40.16 & 38.05 & 38.22 & 37.84 & 38.05 \\
\hline $\mathrm{TiO}_{2}$ & 1.79 & 3.66 & 5.78 & 5.45 & 6.38 & 5.81 & 4.15 & 4.28 & 6.68 & 6.51 & 6.38 & 6.30 \\
\hline $\mathrm{Al}_{2} \mathrm{O}_{3}$ & 14.54 & 14.02 & 13.64 & 13.76 & 12.94 & 13.33 & 12.52 & 12.27 & 12.82 & 13.00 & 13.45 & 13.88 \\
\hline $\mathrm{MnO}$ & 0.10 & 0.05 & 0.00 & 0.05 & 0.13 & 0.08 & 0.10 & 0.00 & 0.06 & 0.06 & 0.00 & 0.07 \\
\hline $\mathrm{MgO}$ & 18.68 & 16.68 & 14.72 & 14.66 & 14.19 & 14.67 & 16.69 & 16.48 & 14.39 & 14.63 & 13.81 & 14.96 \\
\hline $\mathrm{NiO}$ & 0.16 & 0.09 & 0.05 & 0.01 & 0.01 & 0.05 & 0.11 & 0.00 & 0.02 & 0.05 & 0.00 & 0.00 \\
\hline $\mathrm{CaO}$ & 0.01 & 0.00 & 0.00 & 0.00 & 0.00 & 0.00 & 0.03 & 0.00 & 0.00 & 0.00 & 0.00 & 0.00 \\
\hline $\mathrm{Na}_{2} \mathrm{O}$ & 0.07 & 0.17 & 0.33 & 0.41 & 0.25 & 0.19 & 0.10 & 0.11 & 0.25 & 0.16 & 0.09 & 0.23 \\
\hline $\mathrm{K}_{2} \mathrm{O}$ & 9.39 & 9.41 & 9.06 & 9.14 & 9.42 & 9.48 & 8.84 & 9.25 & 8.81 & 9.22 & 9.34 & 9.03 \\
\hline
\end{tabular}

of oceanic island basalts (OIB) (Dostal et al. 1988, 1991; Zhi et al. 1990; Liu et al. 1994).

$\mathrm{Sr}-\mathrm{Nd}-\mathrm{Pb}$ isotopes

Initial $\mathrm{Sr}-\mathrm{Nd}-\mathrm{Pb}$ isotopic ratios were calculated for the emplacement age of $127 \mathrm{Ma}$. The Yinan gabbros have highly radiogenic ${ }^{87} \mathrm{Sr} /{ }^{86} \mathrm{Sr}(t)$ ranging from 0.7105 to 0.7112 and unradiogenic ${ }^{143} \mathrm{Nd} /{ }^{144} \mathrm{Nd}$ with initial $\epsilon_{\mathrm{Nd}}(t)$ values ranging from -15.4 to -12.6 (Table 6). These isotopic compositions are similar to those reported for the Fangcheng Mesozoic basalts, but contrast with those of the Cenozoic basalts, which have low ${ }^{87} \mathrm{Sr} /{ }^{86} \mathrm{Sr}$ (mostly <0.7050) and radiogenic ${ }^{143} \mathrm{Nd} /{ }^{144} \mathrm{Nd}$ $\left(\epsilon_{\mathrm{Nd}}=0-7\right)$ (Fig. 8a).

The Yinan gabbros also have distinctive $\mathrm{Pb}$ isotopic compositions with ${ }^{206} \mathrm{~Pb} /{ }^{204} \mathrm{~Pb},{ }^{207} \mathrm{~Pb} /{ }^{204} \mathrm{~Pb}$ and ${ }^{208} \mathrm{~Pb} /{ }^{204} \mathrm{~Pb}$ ratios in the range $17.45-17.26,15.48-15.55$ and 37.45-38.02, respectively (Table 6). Like the Cenozoic basalts, all the samples plot above the North
Hemisphere Reference Line (Hart 1984). Compared to the Cenozoic basalts, the Yinan samples are characterized by higher ${ }^{207} \mathrm{~Pb} /{ }^{204} \mathrm{~Pb}$ ratios at given ${ }^{206} \mathrm{~Pb} /{ }^{204} \mathrm{~Pb}$ (Fig. 9a, b).

\section{Discussion}

\section{Petrogenesis}

Melts or cumulate? It is important to assess whether the Yinan gabbros are cumulates or solidified melts or mixtures of the two. The following observations suggest that most of studied gabbros were not very significantly affected by crystal cumulation:

1. The Yinan gabbros define compositional trends that are coherent with the Mesozoic erupted magmas (Fig. 6). 
Table 5 Major and trace element compositions of the Yinan gabbros

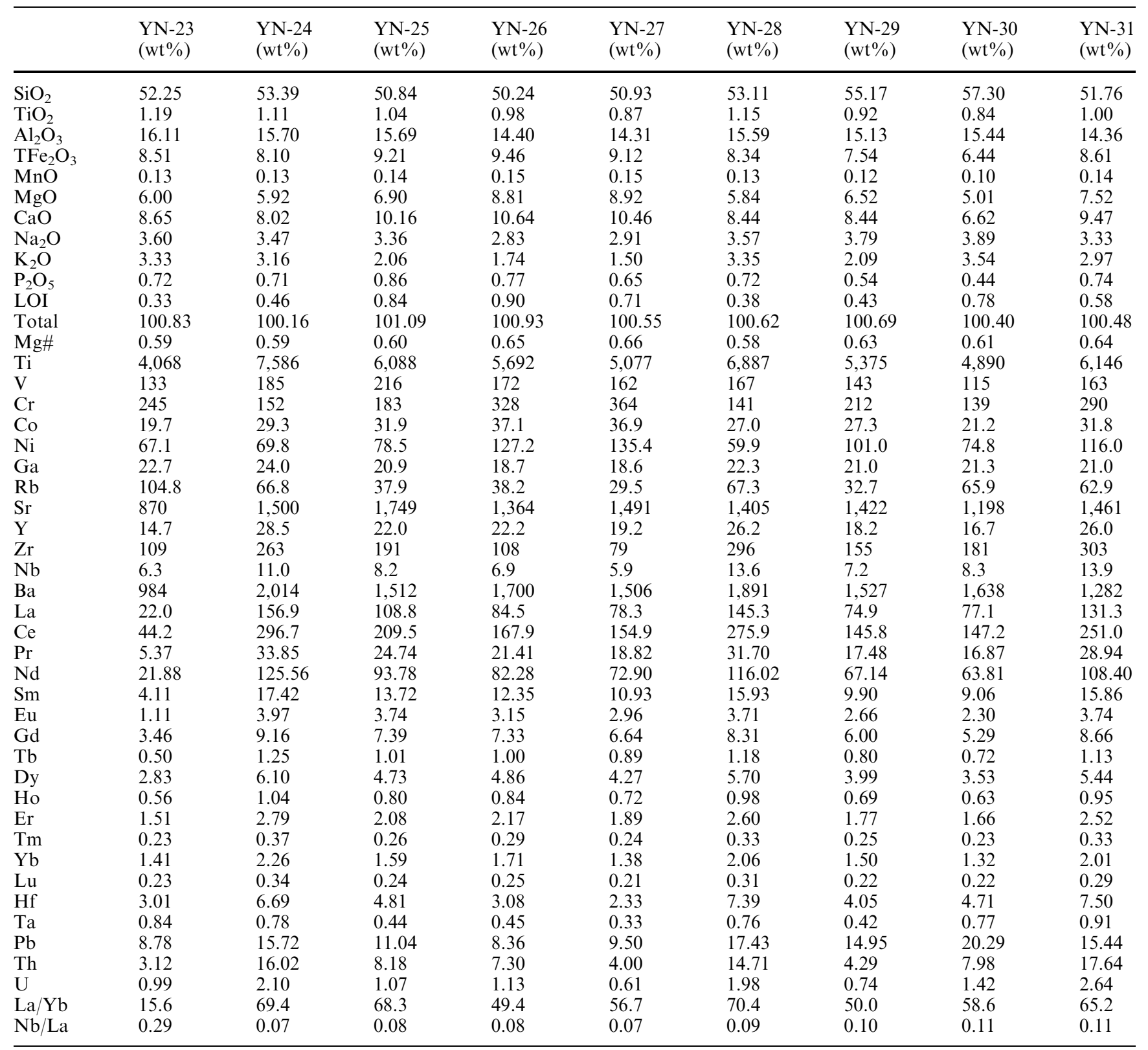

2. Neither layered structure in the outcrop nor textural evidence for crystal cumulation in thin sections have been observed.

3. Forsterite contents $\left(\mathrm{Fo}_{57-66}\right)$ in Ols of the Yinan gabbros are lower than those typical of layered gabbroic intrusions $\left(\mathrm{FO}_{90-75}\right)$, but similar to those in the roof zone potassic gabbronorites from Black Hill, South Australia (Turner, 1996). Furthermore, compared with typical cumulative gabbros, which are An-rich ( $>\mathrm{An}_{60}$, Beard, 1986), plagioclases in the Yinan samples are relatively poor in anorthite $\left(\mathrm{An}_{21-56}\right)$.

4. The lack of $\mathrm{Eu}$ anomalies contrasts with the pronounced positive $\mathrm{Eu}$ anomaly in other Mesozoic cumulative gabbros in Shandong Province, which are commonly composed of Ol-rich gabbros and troctolites (e.g., the Jinan gabbros, Guo et al. 2001).

5. The presence of large amounts of biotite in the Yinan samples suggests that these biotites are magmatic rather than of near-solidus origin.

The Yinan gabbros are not primary mantle melts judged from their moderate $\mathrm{MgO}$ (mostly <9\%), $\mathrm{Mg \#}$ (0.58-0.66) and Ni contents (67-135 ppm). They are far from the expected composition of melts in equilibrium with mantle peridotites (Frey et al. 1978; Cox 1980). Although these compositional features may alternatively be related to a Fe-rich source (see next sections), the Yinan gabbros must have experienced extensive crystal fractionation from parental magmas, either in 


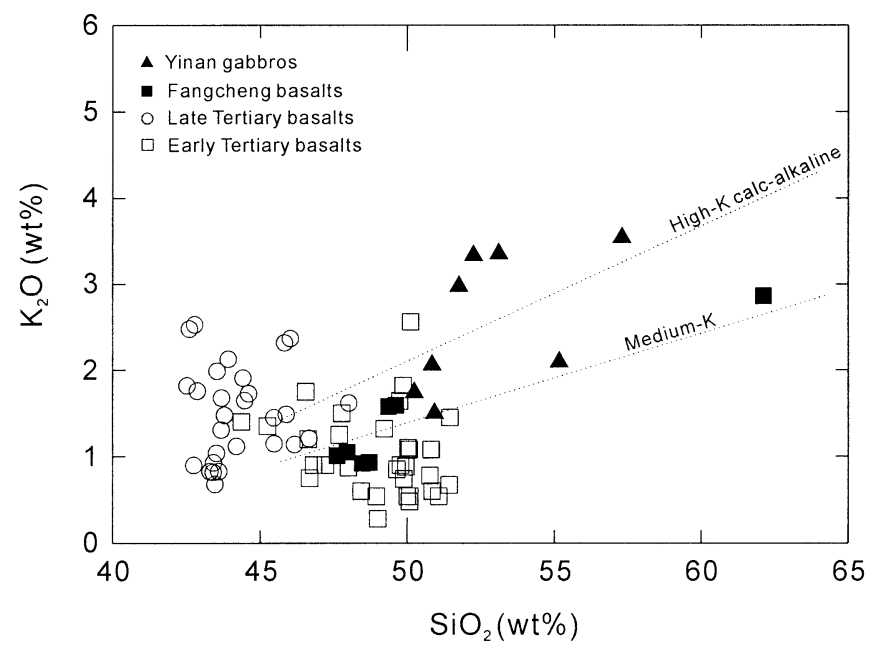

Fig. $5 \mathrm{~K}_{2} \mathrm{O}$ vs $\mathrm{SiO}_{2}$ plot for the Yinan gabbros. The boundaries between medium-K and high- $\mathrm{K}$ calc-alkaline series are after Peccerillo and Taylor (1976). Also shown for comparison are the Mesozoic basalts from Fangcheng (Zhang et al. 2002) and the Cenozoic basalts from Shandong Province (Dostal et al. 1988; 1991; Chen et al. 1990; Liu et al. 1994; Chung 1999)

magma chambers or during the emplacement. The compositional trends of the Yinan gabbros are consistent with fractionation of $\mathrm{Ol}$ and $\mathrm{Cpx}$ from parental magmas. Because $\mathrm{Sr}$ is compatible in plagioclase, the fact that $\mathrm{Sr}$ content remains constant as $\mathrm{MgO}$ decreases (not shown) and the lack of negative $\mathrm{Eu}$ anomalies argue against a significant fractionation of plagioclase. Opx generally occurs as a rim surrounding $\mathrm{Ol}$ crystals (Fig. 2c). This and Opx-magnetite symplectite at the periphery of $\mathrm{Ol}$ indicate the instability of $\mathrm{Ol}$. The replacement of $\mathrm{Ol}$ by Opx may be induced by increasing activity of silica as a result of early crystallization of $\mathrm{Ol}$ (Turner 1996). The late appearance of biotite is consistent with low crystallization temperature and with the buildup of the $\mathrm{H}_{2} \mathrm{O}$ content in the residual magma owing to crystallization of anhydrous phases. The evolution of magmas was further complicated by melt recharge in the magma chamber, as suggested by compositional zoning in $\mathrm{Cpx}$ and reversals in $\mathrm{Mg \#}$ (Fig. 4a).

The preferential stability of biotite and the high concentration of incompatible elements such as $\mathrm{K}, \mathrm{Ba}$, $\mathrm{Rb}$ and REE make the Yinan gabbros very similar to the potassic gabbronorites from Black Hill pluton, South Australia (Turner 1996). The latter occupies the roof zone of an intrusion and is underlain by peridotites, Olrich gabbros and troctolites (Turner, 1996). A similar model can be suggested for the genesis of the Yinan gabbros. The level of exposure of the Yinan gabbros is likely near the top of the original intrusion. This roof zone may be underlain by layered Ol-rich cumulates, although the latter do not outcrop in the Yinan area. Olrich gabbros and troctolites do occur in the Jinan and Zouping gabbroic complexes, which probably correspond to a relatively deep level of exposure.
Involvement of crustal components in magma genesis Enrichment of LILE and depletion of HFSE of the Yinan gabbros are characteristic of volcanic rocks in subduction zones or typical continental crust. However, subduction is not considered plausible in Shandong Province, because at the time of emplacement, western Shandong was too far from the subduction zone of the Paleo-Pacific plate. In addition, movement of the Pacific plate during the Early Cretaceous was characterized by northward strike-slip motion and subduction of the Pacific plate under the Asian continent did not occur until circa $100 \mathrm{Ma}$ (Engebretson et al. 1985). Moreover, as seen from Fig. 8, the isotopic range of oceanic sediments is not sufficient to explain the observed isotopic composition in the Yinan gabbros. The very "enriched" isotopic signature (high ${ }^{87} \mathrm{Sr} /{ }^{86} \mathrm{Sr}$ and ${ }^{207} \mathrm{~Pb} /{ }^{204} \mathrm{~Pb}$ and very low $\epsilon_{\mathrm{Nd}}$ ) of the Yinan gabbros is also difficult to reconcile with the depleted-to-only-moderately-enriched isotopic signatures of arc-related magmas. These distinctive initial isotopic features of the Yinan samples thus provide evidence for the involvement of a component that may have had a long residence time in a continental crust with relatively lower $\mathrm{Sm} / \mathrm{Nd}$ and higher $\mathrm{Rb} / \mathrm{Sr}$ ratios. It remains to assess whether this crustal signature was introduced by contamination during magma ascent or reflects a feature of the mantle source.

Crustal contamination The magmas parental to the Yinan gabbros were well above the solidus of most crustal rocks they passed through and intruded and thus were susceptible to the effects of contamination. Figure $8 \mathrm{~b}$ shows the calculated mixing curve of the enriched mantle-derived basalts and an upper crust. In order to change the $\mathrm{Nd}$ isotopic composition of mantlederived liquid from an $\epsilon_{\mathrm{Nd}}(t)$ of -5 to the observed isotopic composition $(-15)$, an assimilation of $25-35 \%$ of upper crustal materials is required. Involvement of such a high percentage of crustal material cannot be reconciled with the mafic composition of the Yinan gabbros. One may argue that this bulk-mixing model is too simplistic. The more complex processes involving coupled assimilation, fractionation and crystallization (AFC, DePaolo 1981) should produce typical compositional trends, such as concomitant increase in $\mathrm{SiO}_{2}$ and ${ }^{87} \mathrm{Sr} /{ }^{86} \mathrm{Sr}$ ratios, and negative correlation between $\mathrm{SiO}_{2}$ and $\epsilon_{\mathrm{Nd}}$. However, the $\mathrm{Sr}-\mathrm{Nd}$ isotopic ratios of the Yinan gabbros remain virtually unchanged, irrespective of the variation in $\mathrm{SiO}_{2}$ and $\mathrm{MgO}$ (Fig. 10a-d). For instance, the sample with the lowest $\mathrm{SiO}_{2}$ and highest $\mathrm{MgO}$ contents has an isotopic composition similar to that with the highest $\mathrm{SiO}_{2}$ and lowest $\mathrm{MgO}$ contents. Similar behavior is noted for $\mathrm{Pb}$ isotopes except for the most evolved sample (YN-30), which has a slightly lower ${ }^{206} \mathrm{~Pb} /{ }^{204} \mathrm{~Pb}$ (Fig. 10e, f). Given the high sensitivity of $\mathrm{Pb}$ isotopes to crustal contamination, this suggests that crustal contamination, if present, is limited to only the evolved samples.

The homogeneous isotopic composition, however, could be related to melting, assimilation, storage and 
Fig. 6a-h Plots of $\mathrm{SiO}_{2}, \mathrm{Al}_{2} \mathrm{O}_{3}$, $\mathrm{TiO}_{2}, \mathrm{CaO}, \mathrm{TFe}_{2} \mathrm{O}_{3}, \mathrm{Na}_{2} \mathrm{O}, \mathrm{Cr}$ and $\mathrm{Ni}$ against $\mathrm{MgO}$ for the Yinan gabbros. Data sources are the same as in Fig. 5
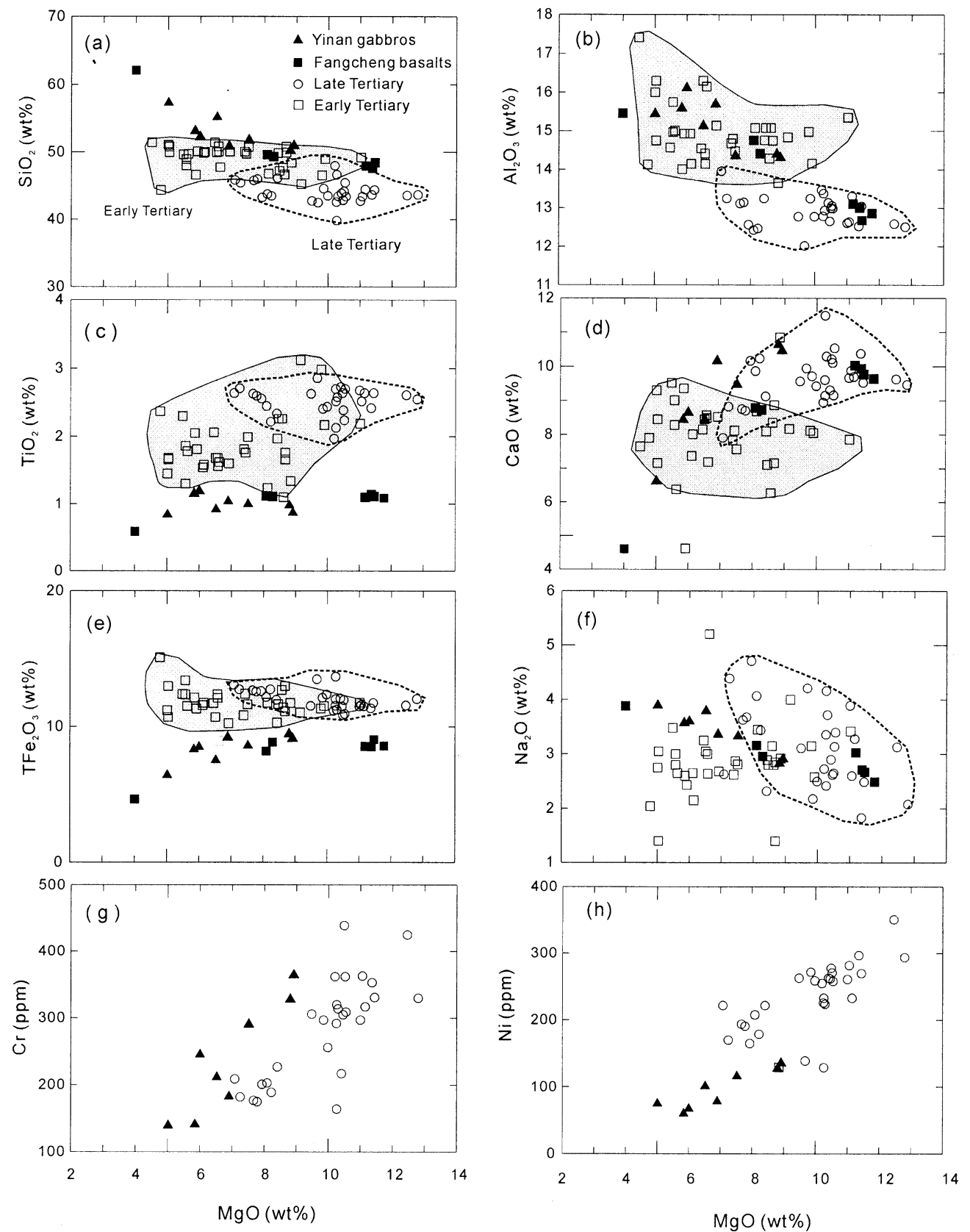

homogenization (MASH) (Hildreth and Moorbath 1988) and/or AFC process in a refilled, tapped magma chamber (Aitcheson and Forrest 1994). It is conceivable that magmas experienced assimilation in a deeper chamber at mid or lower crustal depth, and then fractionated during its ascent to the surface. In the continental setting, a zone of MASH is most likely developed in the lowermost crust and crust-mantle transition, where basaltic magmas become neutrally buoyant and induce local melting, assimilate and mix extensively (Hildreth and Moorbath 1988). In this case, homogenization occurred before crystal fractionation and therefore no correlation between isotopic ratios and differentiation index would be expected (e.g., Hildreth and Moorbath 1988). A relatively deep level at which the fractionation took place is supported by the fact that the main fractionating phases were $\mathrm{Cpx}$ and $\mathrm{Ol}$, but not plagioclase in the Yinan case. Magmas formed in this way should have higher $\mathrm{SiO}_{2}$ and lower $\mathrm{MgO}$ than the original, mantle-derived magma, as a result of mixing of mantle and crust-derived fractions. This contrasts with the magmas generated from the metasomatized mantle. Infiltration of crust-derived fluids/melts can significantly modify isotopic and trace element composition of the mantle source but have only minor effects on major element contents. The least evolved samples from Yinan have $\sim 9 \% \mathrm{MgO}$ and $>350 \mathrm{ppm} \mathrm{Cr}$, which are comparable to the "primitive" Cenozoic basalts (Fig. 6g). The 


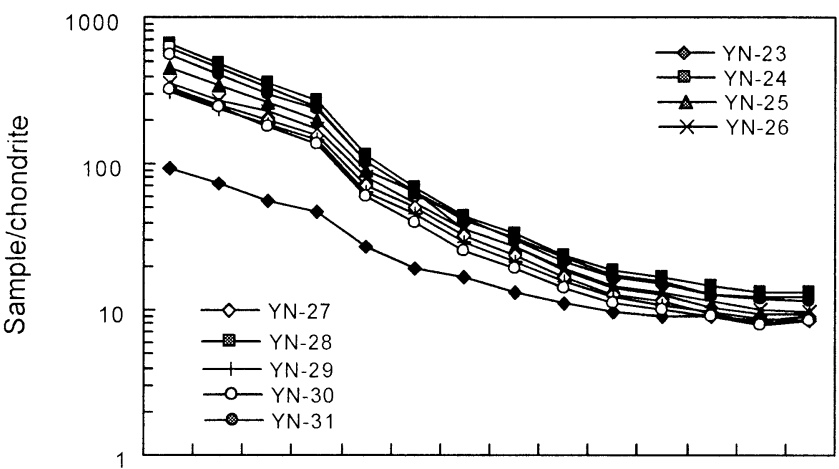

La Ce Pr Nd Sm Eu Gd Tm Dy Ho Er Tb Yb Lu

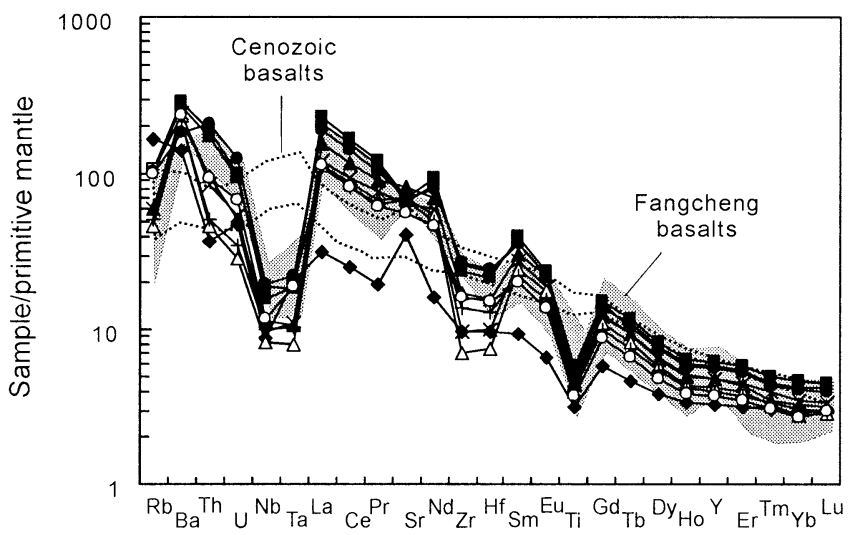

Fig. 7 Rare earth elements (REE) and trace element abundances in whole rocks of the Yinan gabbros. The top shows REE patterns normalized by chondritic values, while the bottom shows multiple trace element spiderdiagrams normalized by primitive mantle values (Sun and McDonough, 1989). The fields for Cenozoic basalts from Shandong and Mesozoic basalts from Fangcheng are outlined for comparison. Data sources are the same as in Fig. 5

basalts from nearby Fangcheng, which show similar isotopic compositions to the Yinan gabbros, have $\mathrm{MgO}$ contents as high as $11.8 \%$ (Zhang et al. 2002). These relatively "primitive" compositions are in conflict with the MASH processes, which commonly generate melts ranging from evolved basalts to dacites (Hildreth and Moorbath 1988). Furthermore, if the Yinan gabbros were formed through MASH at the crust-mantle boundary, their isotopic compositions would be inherited from the lower crust, which is characterized by low ${ }^{87} \mathrm{Sr} /{ }^{86} \mathrm{Sr}(<0.705), \epsilon_{\mathrm{Nd}}$ and unradiogenic $\mathrm{Pb}$ isotopic ratios (Huang et al. 2004; Xu et al. 2004). High ${ }^{87} \mathrm{Sr} /{ }^{86} \mathrm{Sr}$ $(\sim 0.710)$ and radiogenic $\mathrm{Pb}$ isotope for the Yinan gabbros therefore suggest that crustal contamination was not responsible for the crustal signature of the Yinan gabbros. Other evidence against crustal contamination includes (1) the $\mathrm{Nb} / \mathrm{La}$ ratio $(0.07-0.29)$ in the Yinan samples which is significantly lower than estimates for typical crustal components $(\sim 0.4-0.5$; Rudnick and Fountain, 1995; Gao et al. 1998), and (2) the lack of crustal inheritance in the zircon systematics.

$A$ hydrous and hybrid mantle source It is possible that the "crustal signature" of the Yinan gabbros is that of the source. In the conventional $\mathrm{Sr}-\mathrm{Nd}$ isotopic dia-

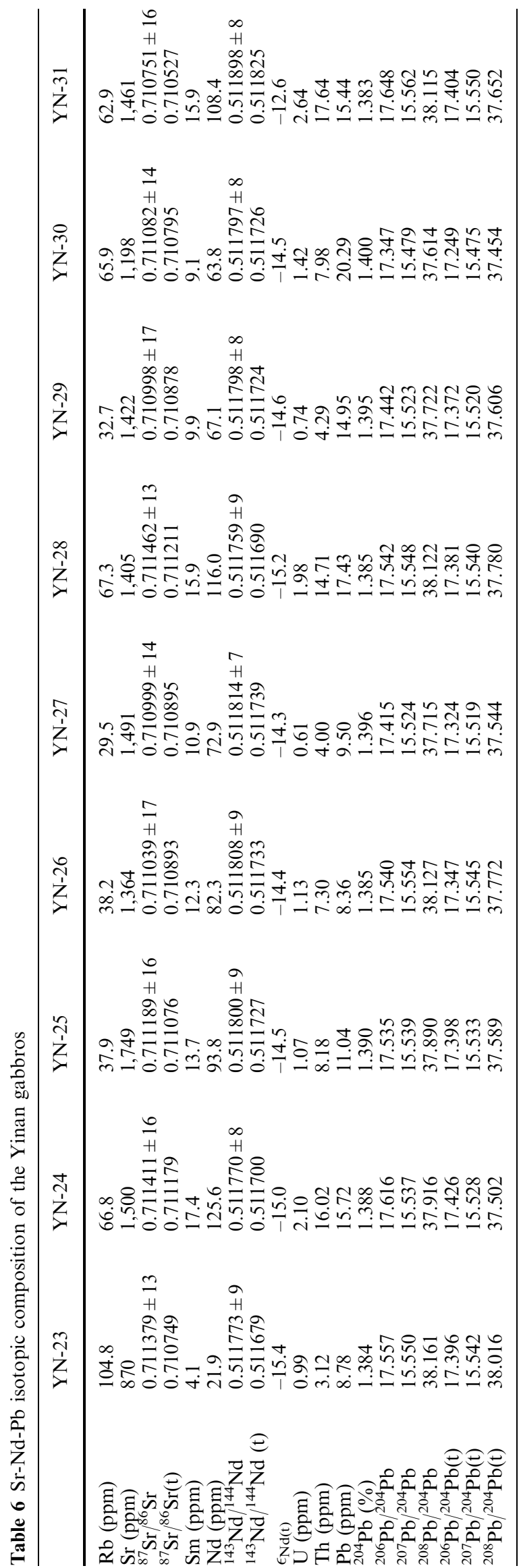



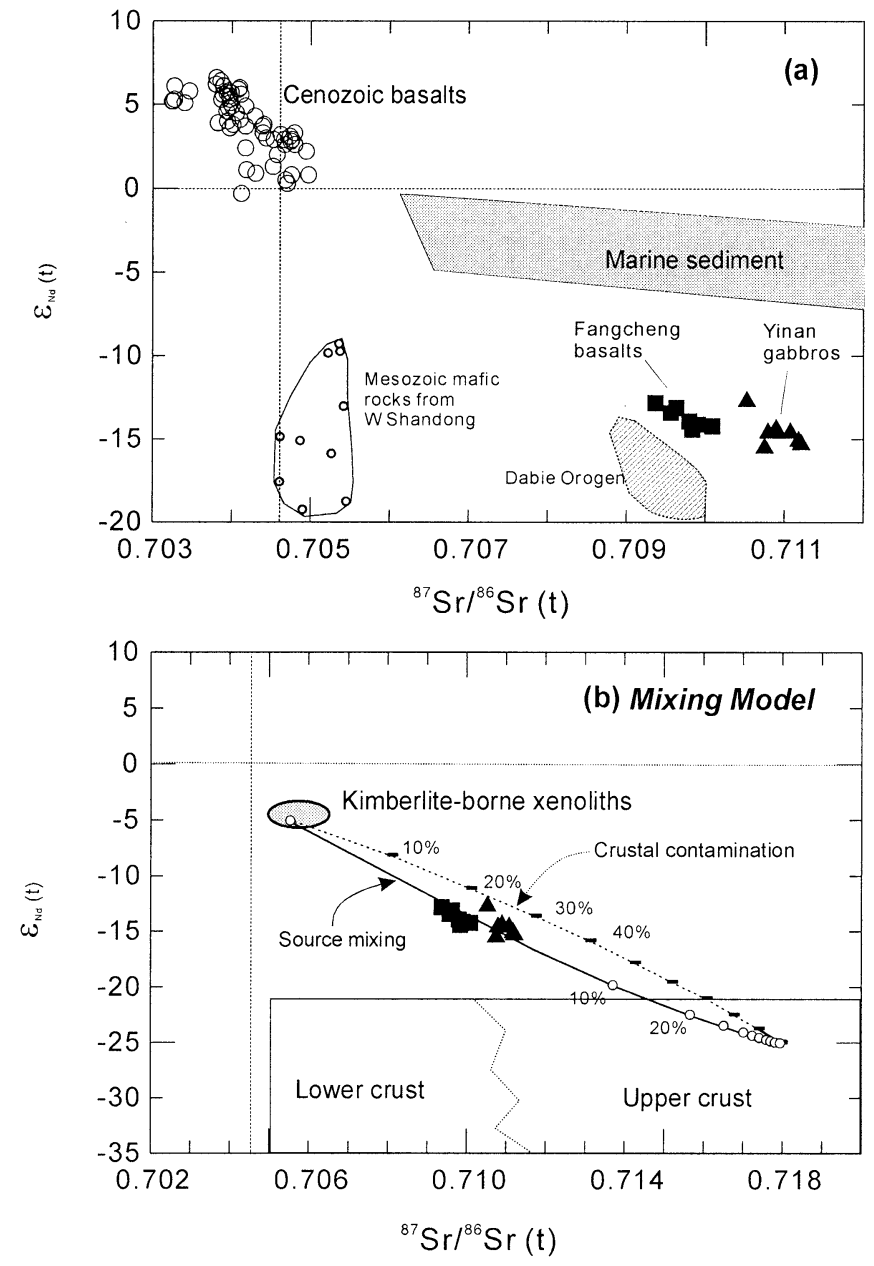

Fig. 8 a Initial $\epsilon_{\mathrm{Nd}}$ versus ${ }^{87} \mathrm{Sr} /{ }^{86} \mathrm{Sr}$ of the Yinan gabbros. Isotope data of the Cenozoic alkaline basalts (Peng et al. 1986; Basu et al. 1991; Song et al. 1990; Liu et al. 1995) and Mesozoic magmas from western Shandong (Guo et al. 2001, 2003) and from Fangcheng (Zhang et al. 2002) are given for comparison. The field for the Dabie mafic and ultramafic intrusions is after Li et al. (1998) and Jahn et al. (1999). Marine sediment data are after Ben Othman et al. (1989) and McLennan et al. (1990). b Diagram showing mixing models for source (solid line) and melt contamination (dotted line). Tick marks show the effect of addition of upper crustal components. The mixing parameters are as follows:

\begin{tabular}{llll}
\hline & Lithospheric mantle & Melt & Upper crust \\
\hline${ }^{87} \mathrm{Sr} /{ }^{86} \mathrm{Sr}$ & 0.7055 & 0.7055 & 0.718 \\
$\mathrm{Sr}, \mathrm{ppm}$ & 20 & 150 & 350 \\
$\epsilon_{\mathrm{Nd}}$ & -5 & -5 & -25 \\
$\mathrm{Nd}, \mathrm{ppm}$ & 1 & 15 & 26 \\
\hline
\end{tabular}

Data for the kimberlite-borne xenoliths are after Zheng and $\mathrm{Lu}$ (1999); composition of continental upper crust is after Taylor and McLennan (1985)

gram, the Yinan gabbros are located in the extended trend of the mantle array, having slightly higher ${ }^{87} \mathrm{Sr} /{ }^{86} \mathrm{Sr}$ and $\epsilon_{\mathrm{Nd}}(t)$ than the mafic-ultramafic rocks from the northern Dabie ultra high pressure (UHP) belt (Fig. 8a). Jahn et al. (1999) interpreted the isotopic composition of the Dabie rocks as a result of mixing between a depleted mantle and a lower crust. This model, however, does not apply to the Yinan case, because there is no evidence for such a depleted mantle protolith beneath the NCC during the Mesozoic. The $\mathrm{Pb}-\mathrm{Sr}$ and $\mathrm{Pb}-\mathrm{Nd}$ isotopic correlations for the Yinan gabbros (Fig. 9c, d) require an old enriched mantle protolith. On the other hand, $\mathrm{Sr}-\mathrm{Nd}-\mathrm{Pb}$ isotopic characteristics suggest that the lower crust may not be a plausible mixing component. The lower crust beneath the NCC is generally characterized by relatively low ${ }^{87} \mathrm{Sr} /{ }^{86} \mathrm{Sr},{ }^{207} \mathrm{~Pb} /{ }^{204} \mathrm{~Pb}$ and ${ }^{206} \mathrm{~Pb} /{ }^{204} \mathrm{~Pb}$ and lower concentrations of incompatible elements (Zhou et al. 2002; Huang et al. 2004). Therefore, lower crustal contaminant cannot account for the high LILE/LREE ratios and high ${ }^{87} \mathrm{Sr} /{ }^{86} \mathrm{Sr}$ and ${ }^{207} \mathrm{~Pb} /{ }^{204} \mathrm{~Pb}$ ratios of the Yinan gabbros (Fig. 9). The latter reflects a time-integrated high ${ }^{235} \mathrm{U} /{ }^{204} \mathrm{~Pb}$ ratio, which is a characteristic of upper crustal materials.

Therefore, upper crustal materials may have been involved in the source of the Yinan gabbros. To test this alternative, we performed a modeling calculation for source mixing in terms of $\mathrm{Sr}-\mathrm{Nd}$ isotopic composition. Little is known about the old mantle protolith, but it should inherit some features of the Paleozoic mantle, which has been sampled by Ordovician kimberlites in Mengyin (Zheng and Lu, 1999). The kimberlite-borne peridotites $\left[\epsilon_{\mathrm{Nd}}(t)=-5\right]$ are thus used as a mantle protolith during the model calculation. The result shows that addition of a few percent of an upper crustal component in an enriched mantle suffices to explain the observed isotopic composition (Fig. 8b). Melting of such a mixed mantle source would yield a melt in which major elements are dominated by the mantle components, while the trace element and isotopic composition are governed by the crustal components.

The nature of the mantle source can further be inferred by comparing the Yinan gabbros with experimental melts (Falloon et al. 1988). Relatively low FeO and $\mathrm{TiO}_{2}$ contents in the Yinan gabbros (Fig. 6c, e) are indicative of a refractory source. Occurrence of significant amount of biotite and the high $\mathrm{K}_{2} \mathrm{O}$ content $(>3 \%)$ of the most "primitive" rocks suggests a hydrous, potassic phase in the source region. Phlogopite and K-rich amphibole may be the likely candidates. The presence of water may trigger the melting of refractory peridotites. As demonstrated by experiments and theoretical considerations, addition of only $0.3 \% \mathrm{H}_{2} \mathrm{O}$ to peridotites lowers its solidus by several hundred degrees (Olafsson and Eggler 1983; Gallagher and Hawkesworth 1992). Moreover, the presence of $\mathrm{H}_{2} \mathrm{O}$ expands the $\mathrm{Ol}$ primary phase volume such that Opx melts incongruently to produce $\mathrm{SiO}_{2}$-rich melts (e.g., Kushiro 1972). As a consequence, melting of hydrated peridotites will produce melts with higher $\mathrm{SiO}_{2}$ and lower $\mathrm{FeO}$ and $\mathrm{CaO}$ than melts produced under anhydrous conditions.

It is worth noting that the Mesozoic magmas have relatively lower $\mathrm{Ni}$ and higher $\mathrm{Cr}$ contents than Cenozoic basalts at comparable $\mathrm{MgO}$ (Fig. 6g, h). Because Ni is compatible in $\mathrm{Ol}$ and $\mathrm{Cr}$ is compatible in $\mathrm{Cpx}$ and 
Fig. 9 Initial ${ }^{207} \mathrm{~Pb} /{ }^{204} \mathrm{~Pb}$ and ${ }^{208} \mathrm{~Pb} /{ }^{204} \mathrm{~Pb}$ versus ${ }^{206} \mathrm{~Pb} /{ }^{204} \mathrm{~Pb}$ for the Yinan gabbros. Data for the Mesozoic Fangcheng basalts (Zhang et al. 2002) and Cenozoic basalts (Peng et al. 1986; Basu et al. 1991; Song et al. 1990) are shown for comparison. Field of lower crust granulites is after Zhou et al. (2002). The fields of MORB, EM1, EM2 and the north hemisphere reference line $(N H R L)$ are taken from Hart (1984) and Zindler and Hart (1986)

Fig. 10a-f Plot of ${ }^{143} \mathrm{Nd} /{ }^{144} \mathrm{Nd}$, ${ }^{87} \mathrm{Sr} /{ }^{86} \mathrm{Sr}$ and ${ }^{206} \mathrm{~Pb} /{ }^{204} \mathrm{~Pb}$ versus $\mathrm{MgO}$ and $\mathrm{SiO}_{2}$
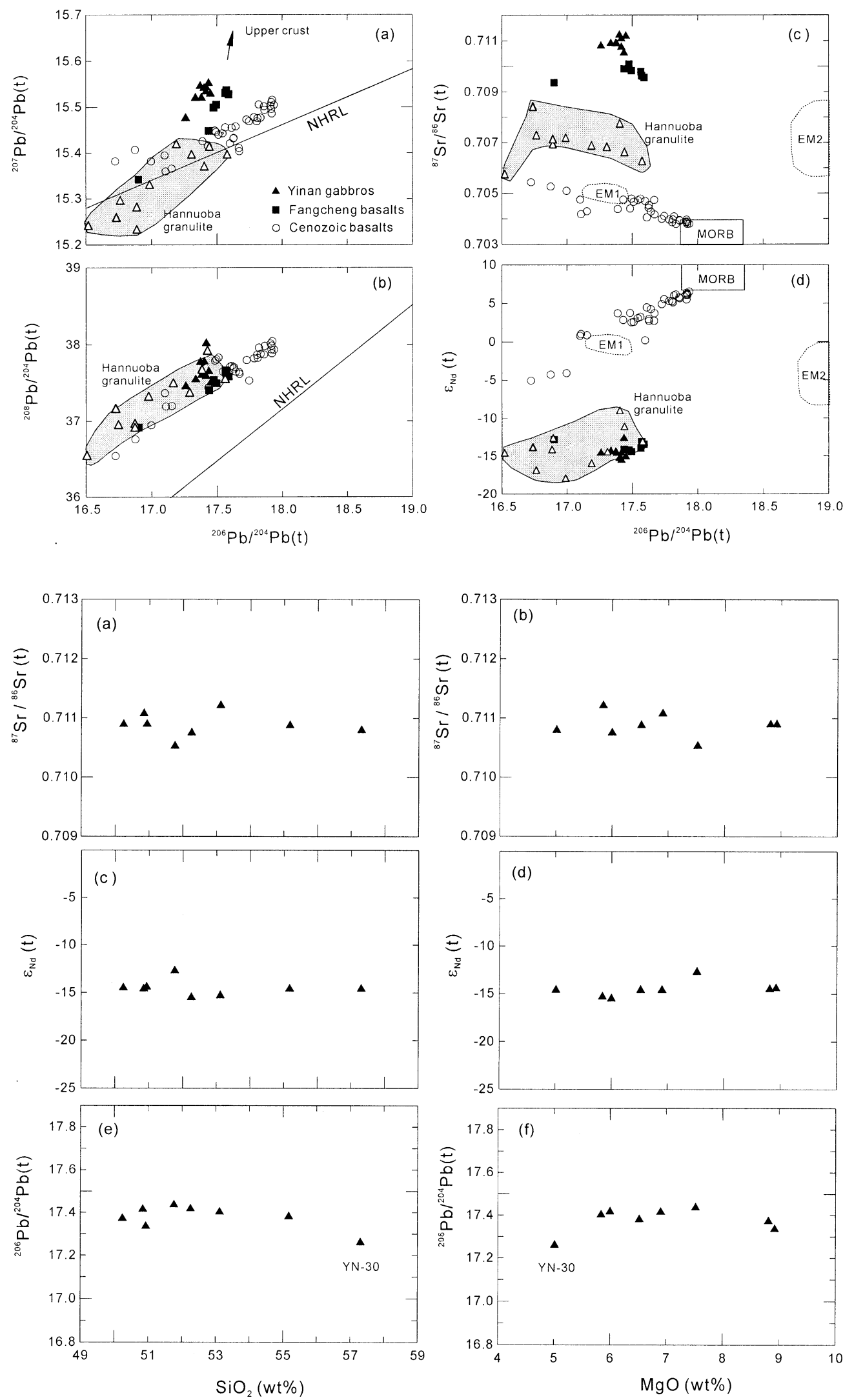

spinel, the compositional characteristics of the Mesozoic magmas imply a pyroxenite vein-plus-peridotite type mantle (Foley 1992), rather than a pure peridotitic source. Such a hybrid, Cpx-rich source can explain the comparable $\mathrm{CaO}$ contents in Mesozoic and Cenozoic rocks (Fig. 6d). 
Mesozoic mantle domains beneath Shandong Province

If crustal contamination is ruled out, the geochemical composition of the Mesozoic mafic rocks can be used to examine the spatial heterogeneity of the mantle lithosphere beneath Shandong Province. Correlation between geographic positions and the isotopic compositions of mafic rocks is noted in this region. Specifically, the lavas and mafic intrusions in the areas (e.g., Jinan, Zouping, Tongshi), which are located west of, but relatively distant from the Tanlu Fault (cf. Fig. 11), show dominant EM1-like isotopic characteristics (low $\epsilon_{\mathrm{Nd}}$ but moderately low ${ }^{87} \mathrm{Sr} /{ }^{86} \mathrm{Sr}$ of $<0.705$ ), whereas those from the proximity of the fault (e.g., Yinan, Fangcheng) and from areas east of the fault (e.g., Jiaodong, Jimo) are all characterized by an EM2-like signature (low $\epsilon_{\mathrm{Nd}}$ and high ${ }^{87} \mathrm{Sr}{ }^{86} \mathrm{Sr}>0.709$ ) (Fan et al. 2001; Zhang et al. 2002; Yang et al. 2004; this study). We propose that two distinct mantle domains were probably present beneath Shandong Province during the Mesozoic. The "lithospheric boundary" between the Mesozoic mantle domains most likely runs NE to SW, roughly parallel to the Tanlu Fault, corresponding to a longitude of $117-118^{\circ} \mathrm{E}$ (Fig. 11). This implies that the Tanlu Fault is not a lithospheric boundary as previously thought by Guo et al. (2003), although more data are needed to confirm this argument.

Guo et al. (2001; 2003) and Fan et al. (2001) interpreted that the mafic magmas with EM1 signature were likely derived from an aged, enriched mantle, which probably was inherited from the Archean lithospheric keel. Carbonatitic melt has been considered responsible for this EM1-type mantle enrichment (e.g., Guo et al. 2003). In contrast, as discussed above, the formation of the EM2-like signature may have been associated with recycling of crustal components into the mantle source. The NE-SW trending provinciality of Mesozoic mantle domains suggests that such an EM2-like signature may be an inherited feature of the subducted continental crust during the Triassic North China-South China collision (e.g., Jahn et al. 1999; Li et al. 1998; Zhang et al. 2002). In this model, the mantle section above the subducting slab acquired the EM2 signature through interaction with fluids derived from the subducted continental slab, which lead to the fractionation of HFSE from LILE. In contrast, the section beyond the subduction-affected area remained intact.

The collision between the North China and South China blocks is usually assumed to be related to northward subduction because of the E-W orientation of the Qinling-Dabie UHP belt (e.g., Yin and Nie 1993). The Su-Lu UHP belt resulted from disruption of the Dabie belt as a consequence of the Cretaceous strike-slip movement along the TLFZ (Xu 1993). This tectonic configuration would imply E-W oriented mantle domains in the NCC with an EM2 type close to and an EM1 type distal to the Dabie UHP belt. The spatial configuration of mantle domains in western Shandong (Fig. 11) is somewhat surprising because the Mesozoic sinistral displacement of the Su-Lu UHP belt along the Tanlu fault (Xu, 1993; Li 1994) cannot transform the composition of the mantle beneath western Shandong from EM1 to EM2. Instead, it requires a westerly oriented subduction of the Yangtze plate along the Su-Lu belt. This is supported by seismic tomographic data that show a westerly dipping slab from the Sulu UHP belt to the interior of the NCC (Xu et al. 2001). It is possible that the collision between North China and South China may have started from the northeast in the late Early Permian time (the Sulu belt) and ended in the southeast in Late Triassic time (the Dabie belt) by clockwise rotation (Zhang 1997). The roughly perpendicular orientation of the Dabie and Sulu UHP belts may have resulted from the irregular geometry of the passive northeastern margin of the South China block prior to collision (Yin and Nie 1993; Zhang 1997).

The intrusion of the Yinan gabbroic complex took place at $\sim 127 \mathrm{Ma}$, significantly postdating the Triassic collision between North China and South China.
Fig. 11 Diagram showing two spatially decoupled mantle domains beneath Shandong Province. Samples from western Shandong have significantly lower ${ }^{87} \mathrm{Sr} /{ }^{86} \mathrm{Sr}$ than those from eastern Shandong. Dashed line denotes the possible boundary that separates these two mantle domains. Data sources: Jinan gabbros and Zouping intrusion (Guo et al. 2001; 2003); Yinan and Tongshi (This study; $\mathrm{Xu}$ et al. 2004); Fangcheng basalts (Zhang et al. 2002); Jimo basalts (Fan et al. 2001); Jiaodong mafic dykes (Yang et al. 2004)

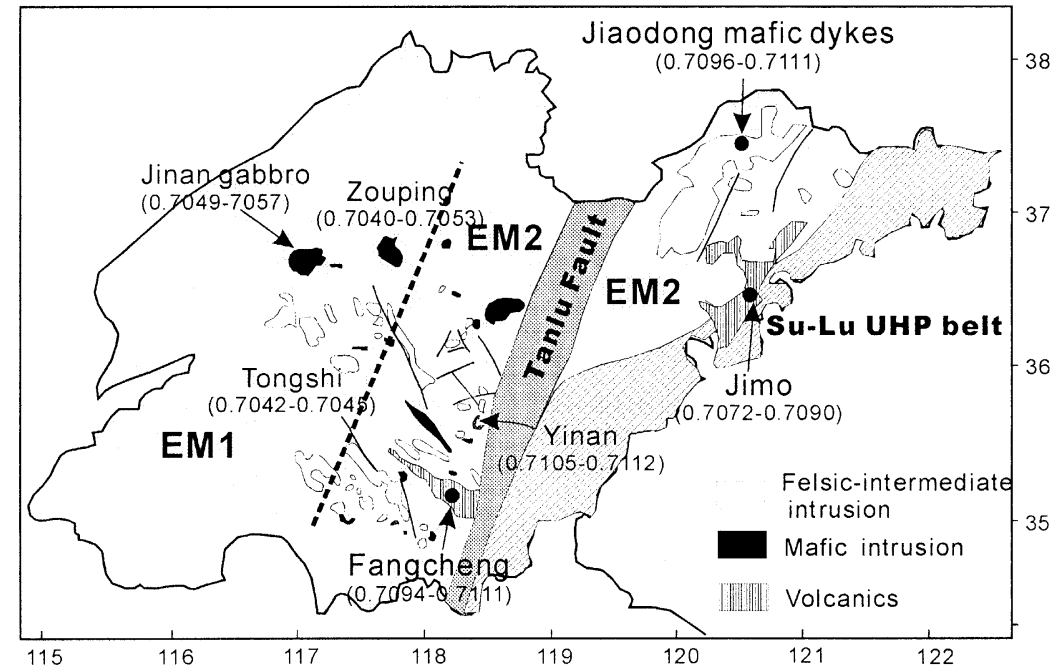


Available structural data suggest a change in the deformational pattern from EW-oriented to NE-oriented at circa 120-130 Ma (Yang et al. 2003). It is thus likely that the intrusion of the gabbros was associated with an extensional regime (Guo et al. 2001, 2003; Xu, 2001; Zhang et al. 2002). Therefore, the generation of the Yinan gabbros may have proceeded in two steps. The initially enriched mantle beneath eastern Shandong may have been metasomatized by fluids derived from subducted continental crust during the North ChinaSouth China collision. This was followed by a postorogenic extension, which triggered the melting of enriched components residing in the lithospheric mantle, giving rise to the formation of the Yinan gabbroic complex.

\section{Conclusions}

1. Mineralogical and textural data suggest that the Yinan gabbros were not significantly affected by cumulus processes. Low forsterite contents in Ol, and the presence of alkali feldspar and biotite make the Yinan gabbros very similar to the potassic gabbronorites from Black Hill, South Australia (Turner 1996). The Yinan gabbros likely represent the roof zone of an intrusion where residual melts subsequent to crystal segregation solidified. The close spatial and temporal association of the volcanic and plutonic igneous suites and their similar compositions lead to the conclusion that they are expressions of the same magmatic activity.

2. Integrated major, trace element and isotopic data suggest that the Yinan gabbros were derived from a hydrous vein-bearing, isotopically enriched lithospheric mantle. Magma generation in the CLM is consistent with the widespread and protracted extension during the late Mesozoic. The U-Pb zircon age of this mafic intrusion, together with available data for the Mesozoic magmatism, suggests that $\sim 130 \mathrm{Ma}$ marked an important period of thermotectonic destruction of the lithospheric keel beneath the NCC.

3. Isotopic data available for the Mesozoic mafic magmas in Shandong Province suggest that two distinct mantle domains, namely EM1- and EM2-like, were present in western and eastern Shandong, respectively. The "lithospheric boundary" between them is located west of, but roughly parallel to the Tanlu Fault. The development of such a lithospheric configuration was probably related to westerly continental subduction during the Triassic North China-South China collision. Supported by seismic tomographic data, this model implies that the collision between North China and South China may have initiated from the northeast in the late Early Permian time and ended in the southeast in late Triassic time by clockwise rotation.
Acknowledgements J.F. Xu and Q. Wang assisted the fieldwork. We thank Y. Liu, X.L. Tu, X.R. Liang and R.H. Xu for technical assistance with ICP-MS and TIMS analyses. Discussions with Dr. X.-H. Li and Dr. J.-H. Yang were very helpful. Financial support from the National Natural Science Foundation of China (49925308) and the Chinese Academy of Sciences (the "Bairen" Project) is gratefully acknowledged. Electron probe analyses were made possible through a visiting fellowship awarded to Y.-G. Xu by the NSC of Taiwan. Dr. L. Reisberg and Dr. Pencat provided careful and constructive reviews that helped improve the manuscript considerably.

\section{References}

Aitcheson, Forrest (1994) Quantification of crustal contamination in open magmatic systems. J Petrol 35: 461-488

Basu AR, Wang JW, Huang WK, Xie GH, Tatsumoto M (1991) Major element, REE and $\mathrm{Pb}, \mathrm{Nd}$ and $\mathrm{Sr}$ isotopic geochemistry of Cenozoic volcanic rocks of eastern China: implications for origin from suboceanic-type mantle reservoirs. Earth Planet Sci Lett 105:149-169

Beard JS (1986) Characteristic mineralogy of arc-related cumulate gabbros: implications for the tectonic setting of gabbroic plutons and for andesite genesis. Geology 14:848-851

Ben Othman D, White WM, Patchett J (1989) The geochemistry of marine sediments, island arc magma genesis and crust-mantle recycling. Earth Planet Sci Lett 94:1-21

Chen DG, Zhou HT, Yang JD, Wang YX (1990) Isotopic evidence for petrogenesis of Cenozoic volcanic rocks and characteristics of mantle source from Shandong, Anhui and Jiangsu. In: Liu RX (ed) Characteristics and dynamics of the upper mantle in eastern China. Seismologic, Beijing, pp. 124 131 (in Chinese)

Chung SL (1999) Trace element and isotope characteristics of Cenozoic basalts around the Tanlu fault with implications for the eastern plate boundary between North and South China. J Geol 107:301-312

Cox KG (1980) A model for flood basalt volcanism. J Petrol 21:629-650

DePaolo DJ (1981) Trace element and isotopic effects of combined wallrock assimilation and fractional crystallization. Earth Planet Sci Lett 53:189-202

Dostal J, Dupuy C, Zhai M, Zhi X (1988) Geochemistry and origin of Pliocene alkali basaltic lavas from Anhui-Jiangsu, eastern China. Geochem J 25:165-176

Dostal J, Zhi X, Muehlenbachs K, Dupuy C, Zhai M (1991) Geochemistry of Cenozoic alkalic lavas from Shandong Province, eastern China. Geochem J 28:1-16

Engebretson DC, Cox A, Gordon RG (1985) Relative motions between oceanic and continental plates in the Pacific basins. Geol Soc Am Spec Pap 206:1-59

Falloon TJ, Green DH, Harton CJ, Harris KJ (1988) Anhydrous partial melting of a fertile and depleted peridotite from 2 to $30 \mathrm{~kb}$ and application to basalt petrogenesis. J Petrol 29:1257-1282

Fan WM, Guo F, Wang YJ, Lin G, Zhang M (2001) Post-orogenic biomodal volcansim along the Sulu orogenic belt in eastern China. Phys Chem Earth (A) 26:733-746

Fan WM, Menzies MA (1992) Destruction of aged lower lithosphere and accretion of asthenosphere mantle beneath eastern China. Geotectonica Metallogenia 16:171-180

Fan WM, Zhang HF, Baker J, Javis KE, Mason PRD, Menzies MA (2000) On and off the North China craton: where is the Archean keel? J Petrol 41:933-950

Foley SF (1992) Vein-plus-wall rock melting mechanisms in the lithosphere and the origin of potassic alkaline magmas. Lithos 28:435-453

Frey FA, Green DH, Roy SD (1978) Integrated models of basalt petrogenesis: a study of quartz tholeiites to olivine melilitites from southeastern Australia utilizing geochemical and experimental petrological data. J Petrol 19:463-513 
Gallagher K, Hawkesworth CJ (1992) Dehydration melting and the generation of continental flood basalts. Nature 358:57-59

Gao S, Luo TC, Zhang BR, Zhang HF, Han YW, Zhao ZD, Hu YK (1998) Chemical composition of the continental crust as revealed by studies in East China. Geochim Cosmochim Acta 62:1959-1975

Gao S, Rudnick RL, Carlson RW, McDonough WF, Liu YS (2002) Re-Os evidence for replacement of ancient mantle lithosphere beneath the North China Craton. Earth Planet Sci Lett 198:307-322

Griffin WL, Zhang AD, O'Reilly SY, Ryan G (1998) Phanerozoic evolution of the lithosphere beneath the Sino-Korean Craton. In: Flower M, Chung SL, Lo CH, Lee TY (eds) Mantle dynamics and plate interactions in east Asia. AGU Geodynamic Series 27:107-126

Guo F, Fan WM, Wang YJ, Lin G (2001) Late Mesozoic mafic intrusive complexes in North China Block: constraints on the nature of subcontinental lithospheric mantle. Phys Chem Earth (A) 26:759-771

Guo F, Fan WM, Wang YJ, Lin G. (2003) Geochemistry of late Mesozoic mafic magmatism in west Shandong Province, eastern China: characterizing the lost lithospheric mantle beneath the North China Block. Geochem J 40:63-77

Hart SR (1984) A large-scale isotope anomaly in the Southern Hemisphere mantle. Nature 309:753-757

Hildreth W, Moorbath S (1988) Crustal contribution to arc magmatism in the Andes of Central Chile. Contrib Mineral Petrol 98:455-489

Huang XL, Xu YG, Liu DY (2004) Geochronology, petrology and geochemistry of the granulite xenoliths from Nushan, eastern China: implication for a heterogeneous lower crust beneath the Sino-Korean Craton. Geochim Cosmochim Acta 68:127-149

Jahn BM, Auvray B, Cornichet J, Bai YL, Shen QH, Liu DY (1987) 3.5 Ga-old amphibolites from eastern Hebei province China: field occurrence, petrography, $\mathrm{Sm}-\mathrm{Nd}$ isochron age and REE geochemistry. Precam Res 34:311-346

Jahn BM, Wu FY, Lo CH, Tsai CH (1999) Crust-mantle interaction induced by deep subduction of continental crust: geochemical and $\mathrm{Sr}-\mathrm{Nd}$ isotopic evidence from post-collisional mafic-ultramafic intrusions of the northern Dabie complex, central China. Chem Geol 157:119-146

Kushiro I (1972) Effect of water on the composition of magmas formed at high pressure. J Petrol 13:311-344

Li SG, Nie YH, Hart SR, Zheng SG. (1998) Upper mantle-deep subducted continental crust interaction: (II) $\mathrm{Sr}$ and $\mathrm{Nd}$ isotopic constraints on the syn-collisional mafic to ultramafic intrusions in the northern Dabieshan, eastern China. Sci China Ser D 28:18-22

Li ZX (1994) Collision between the North and South China blocks: a crustal-detachment model for suturing in the region east of the Tanlu fault. Geology 22:739-742

Liu CQ, Masuda A, Xie GH (1994) Major- and trace-element compositions of Cenozoic basalts in eastern China: petrogenesis and mantle source. Chem Geol 114:19-42

Liu CQ, Xie GH, Masuda A (1995) Geochemistry of Cenozoic basalts from eastern China (II): $\mathrm{Sr}, \mathrm{Nd}$ and $\mathrm{Ce}$ isotopic compositions. Geochimica 24:203-214 (in Chinese with English abstract)

Liu DY, Nutman AP, Compston W, Wu JS, Shen QH (1992) Remnants of 3800 crust in the Chinese Part of the Sino-Korean craton. Geology 20:339-342

Ludwig KR (2001a) Squid 1.02. In: A user manual, Berkeley. Berkeley Geochronological Center Special Publication, 1-219

Ludwig KR (2001b) Using Isoplot/EX, version 2.49. In: A geochronological toolkit for Microsoft Excel, Berkeley. Berkeley Geochronological Center Special Publication, 1-55

McLennan SM, Taylor SR, McCulloch MT, Maynard JB (1990) Geochemical and $\mathrm{Nd}-\mathrm{Sr}$ isotopic composition of deep-sea turbidites. Geochim Cosmochim Acta 54:2015-2050
Menzies MA, Fan WM, Zhang M (1993) Palaeozoic and Cenozoic lithoprobes and the loss of $>120 \mathrm{~km}$ of Archaean lithosphere, Sino-Korean craton, China. In: Prichard HM, Alabaster T, Harris NBW, Neary CR (eds) Magmatic processes and plate tectonics. Geological Society Special Publication 76:71-78

Menzies MA, Xu YG (1998) Geodynamics of the North China Craton. In: Flower M, Chung SL, Lo CH, Lee TY (eds) Mantle dynamics and plate interactions in east Asia. AGU Geodynamic Series 27:155-165

Olafsson M, Eggler DH (1983) Phase relations of amphibole, amphibole, amphibole-carbonate and phlogopite-carbonate peridotite: petrological constraints on the asthenosphere. Earth Planet Sci Lett 64:305-315

Peccerillo A, Taylor SR (1976) Geochemistry of Eocene calcalkaline volcanic rocks from the Kastamonu, northern Turkey. Contrib Mineral Petrol 58:63-81

Peng ZC, Zartman RE, Futa E, Chen DG (1986) Pb-, Sr- and Ndisotopic systematics and chemical characteristics of Cenozoic basalts, eastern China. Chem Geol 59:3-33

Rudnick RL, Fountain DM (1995) Nature and composition of the continental crust: a lower crustal perspective. Rev Geophys 33:267-309

Song Y, Frey FA, Zhi X (1990) Isotopic characteristics of Hannuoba basalts, eastern China: implications for their petrogenesis and the composition of subcontinental mantle. Chem Geol 85:35-52

Sun SS, McDonough WF (1989) Chemical and isotopic systematics of oceanic basalts: implications for mantle composition and processes. In: Saunders AD, Norry MJ (eds) Magmatism in the ocean basins. Geol Soc Spec Publ 42:313-345

Tan D, Lin J (1994) Mesozoic potassic magma province on North China Platform. Seismological, Beijing

Tanaka T, Togashi S, Kamioka $\mathrm{H}$, Amakawa $\mathrm{H}$, Kagami $\mathrm{H}$, Hamamoto T, Yuhara M, Orihashi Y, Yoneda S, Shimizu H, Kunimaru T, Takahashi K, Yanagi T, Nakano T, Fujimaki H, Shinjo R, Asahara Y, Tanimizu M, Dragusanu C (2004) JNdi1:a neodymium isotopic reference in consistency with LaJolla neodymium. Chem Geol 168:279-281

Taylor HP, McLennan SM (1985) The continental crust: its composition and evolution. Blackwell, Oxford

Turner SP (1996) Petrogenesis of the late-Delamerian gabboric complex at Black Hill, South Australia: implications for convective thinning of the lithospheric mantle. Mineral Petrol 56:51-89

Williams IS, Buick IS, Cartwright I (1996) An extended episode of early Mesoproterozoic metamorphic fluid flow in the Reylolds Range, central Australia. J Metamorphic Geol 14:29-47

Xu JW (1993) The Tancheng-Lujiang wrench fault system. Wiley, NewYork

Xu PF, Liu FT, Wang QC, Cong BL, Chen H (2001) Slab-like high velocity anomaly in the uppermost mantle beneath Dabie-Sulu Orogen. Geophys Res Lett 28:1847-1850

Xu W, Chi X, Yuan C, Wang W (1993) Mesozoic dioritic rocks and deep-seated inclusion in Central North China Platform. Geological, Beijing

$\mathrm{Xu}$ Y-G (2001) Thermo-tectonic destruction of the Archaean lithospheric keel beneath eastern China: evidence, timing and mechanism. Phys Chem Earth A 26:747-757

Xu Y-G (2002) Evidence for crustal components in mantle source and constraints on recycling mechanism: pyroxenite xenoliths from Hannuoba, North China. Chem Geol 182:301-322

Xu Y-G, Huang XL, Ma JL, Wang YB, Iizuka Y, Xu JF, Wang Q, Wu XY (2004) Crustal-mantle interaction during the thermotectonic reactivation of the North China Craton: SHRIMP zircon $\mathrm{U}-\mathrm{Pb}$ age, petrology and geochemistry of Mesozoic plutons in western Shandong. Contrib Mineral Petrol 147: 750-767

Yang JH, Chung SL, Zhai MG, Zhou XH (2004) Geochemical and $\mathrm{Sr}-\mathrm{Nd}-\mathrm{Pb}$ isotopic compositions of mafic dikes from the Jiaodong Peninsula, China: Evidence for vein-plus-peridotite melting in the lithospheric mantle. Lithos 73:145-160 
Yang JH, Wu FY, Wilde SA (2003) A review of the geodynamic setting of large-scale Late Mesozoic gold mineralization in the North China Craton: An association with lithospheric thinning. Ore Geol Rev 23:125-152

Yin A, Nie SY (1993) An indentation model for the North and South China collision and the development of Tanlu and Honam fault systems. Tectonics 12:801-813

Zhang HF, Sun M, Zhou XH, Fan WM, Zhai MG, Yin JF (2002) Mesozoic lithospheric destruction beneath the North China Carton: evidence from major-, trace-element and $\mathrm{Sr}-\mathrm{Nd}-\mathrm{Pb}$ isotope studies of Fangcheng basalts. Contrib Mineral Petrol 144:241-253

Zhang KJ (1997) North and South China collision along the eastern and southern North China margins. Tectonophysics 270:145-156
Zheng JP, Lu FX (1999) Mantle xenoliths from kimberlites, Shandong and Liaoning: Palaeozoic mantle character and its heterogeneity. Acta Petrol Sin 15:65-74 (in Chinese with English Abstract)

Zhi X, Song Y, Frey FA, Feng J, Zhai M (1990) Geochemistry of Hannuoba basalts, eastern China: constraints on the origin of continental alkalic and tholeiitic basalt. Chem Geol 88:1-33

Zhou XH, Sun M, Zhang GH, Chen SH (2002) Continental crust and lithospheric mantle interaction beneath North China: isotopic evidence from granulite xenoliths in Hannuoba, Sino-Korean Craton. Lithos 62:111-124

Zindler A, Hart SR (1986) Chemical geodynamics. Ann Rev Earth Planet Sci 14:493-571 